WSRC-TR-2003-00554, Rev. 0

\title{
Keywords:
}

Activated carbon,

Hematite, sodium phosphate

Cancrinite, Uranium, Plutonium,

Neptunium, Loading capacity.

\section{Identification of Tank 50H Solids Components Responsible for Removal of Dissolved Actinides (U)}

Authors: L. N. Oji and D. T. Hobbs

Publication Date: January 10, 2004

Westinghouse Savannah River Company

Savannah River Site

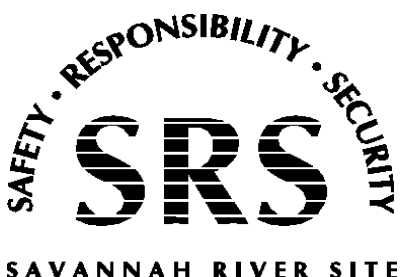

Aiken, SC 29808 
This page was intentionally left blank 
This document was prepared in conjunction with work accomplished under Contract No. DE-AC09-96SR18500 with the U. S. Department of Energy.

\section{DISCLAIMER}

This report was prepared as an account of work sponsored by an agency of the United States Government. Neither the United States Government nor any agency thereof, nor any of their employees, makes any warranty, express or implied, or assumes any legal liability or responsibility for the accuracy, completeness, or usefulness of any information, apparatus, product or process disclosed, or represents that its use would not infringe privately owned rights. Reference herein to any specific commercial product, process or service by trade name, trademark, manufacturer, or otherwise does not necessarily constitute or imply its endorsement, recommendation, or favoring by the United States Government or any agency thereof. The views and opinions of authors expressed herein do not necessarily state or reflect those of the United States Government or any agency thereof.

This report has been reproduced directly from the best available copy.

Available for sale to the public, in paper, from: U.S. Department of Commerce, National Technical Information Service, 5285 Port Royal Road, Springfield, VA 22161, phone: (800) 553-6847, fax: (703) 605-6900

email: orders@ntis.fedworld.gov

online ordering: http://www.ntis.gov/help/index.asp

Available electronically at http://www.osti.gov/bridge

Available for a processing fee to U.S. Department of Energy and its contractors, in paper, from: U.S. Department of Energy, Office of Scientific and Technical Information, P.O. Box 62, Oak Ridge, TN 37831-0062,

phone: (865)576-8401,

fax: (865)576-5728

email: $\underline{\text { reports@ adonis.osti.gov }}$ 


\section{SUMMARY}

As part of preparations to use the Tank $50 \mathrm{H}$ as a receiving tank for the salt supernate solution designed to feed the Saltstone Facility, a follow up study has been completed to identify the Tank $50 \mathrm{H}$ solids components responsible for the removal of plutonium and neptunium from synthetic salt solution. Identification of these sorbents will also help determine whether the existence of these absorbents is limited to the Tank $50 \mathrm{H}$ or more widespread in the High Level Waste system and thus may pose a greater impact.

The primary results of this batch experimental investigation with synthetic salt solution bearing plutonium, uranium and neptunium are:

- The removal of plutonium and neptunium from synthetic salt solution by Tank $50 \mathrm{H}$ solids is attributed to the presence of the old ETF granular activated carbon and transition metal oxides, mostly iron and manganese oxides, in Tank $50 \mathrm{H}$ solids. These components of the Tank $50 \mathrm{H}$ solids are known active sorbents of both plutonium and neptunium.

- Both activated carbon and iron oxide (hematite), which are components of Tank $50 \mathrm{H}$ solids, contribute to the removal of $\mathrm{Pu}$ and $\mathrm{Np}$ by Tank $50 \mathrm{H}$ solids and in combination, they account for about $30 \%$ of the $\mathrm{Pu}$ and $\mathrm{Np}$ removed by Tank $50 \mathrm{H}$ solids.

- Nitrated cancrinite, potassium tetraphenylborate and scintillation cocktail in contact with simulant salt solution containing uranium, plutonium and neptunium do not show any measurable tendency to remove or precipitate these actinides from salt solution.

- The two forms of activated carbon investigated in these tests show measurable affinity for plutonium and neptunium.

- The new ETF activated carbon did not precipitate or remove any measurable amount of uranium from the simulant salt solution, while the old ETF granular activated carbon removed less than $10 \%$ of the uranium.

- The new ETF activated carbon exhibits lower affinity for plutonium and neptunium than the old ETF granular activated carbon.

- The old ETF granular activated carbon and iron oxide (hematite) exhibit high affinity for both plutonium and neptunium.

- Hematite exhibits greater affinity for plutonium and neptunium than either of the ETF activated carbons. 
- Plutonium and neptunium loading capacities onto "neat" old ETF granular activated carbon are, respectively, $3.6 \pm 0.22$ and $7.9 \pm 0.52 \mu \mathrm{g}$ per gram of old ETF granulated activated carbon.

- Plutonium and neptunium loading capacity onto "neat" new ETF activated carbon are, respectively, $1.30 \pm 0.07$ and $4.4 \pm 0.44 \mu \mathrm{g}$ per gram of new ETF activated carbon.

- The loading capacity for plutonium and neptunium onto hematite are, respectively, $5.5 \pm 0.38$ and $>10 \mu$ g per gram of hematite.

- Plutonium loading capacity onto the Tank $50 \mathrm{H}$ solids $(2.01 \mu \mathrm{g}$ per gram of Tank $50 \mathrm{H}$ solids) is about $60 \%$ of plutonium loading capacity onto "neat" old ETF granular activated carbon and $40 \%$ of plutonium loading capacity onto "neat" hematite.

- Neptunium loading capacity onto the Tank $50 \mathrm{H}$ solids $(4.48 \mu \mathrm{g}$ per gram of Tank $50 \mathrm{H}$ solids) is about $50 \%$ of plutonium loading capacity onto "neat" ETF granular activated carbon and less than $50 \%$ of neptunium loading capacity onto "neat" hematite (iron oxide).

Additional testing to verify if other transition metal oxides $\left(\mathrm{MnO}_{2}\right.$ and $\left.\mathrm{ZnO}\right)$ are responsible for actinide removal not accounted for by the presence of activated carbon and hematite are recommended. 
WSRC-TR-2003-00554, Rev. 0

Page 6 of 38

\section{TABLE OF CONTENTS}

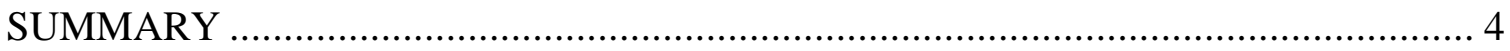

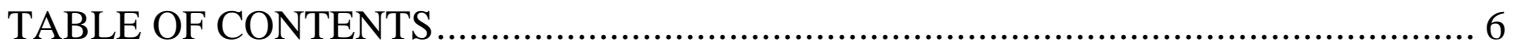

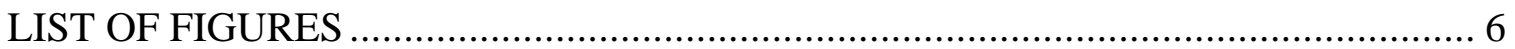

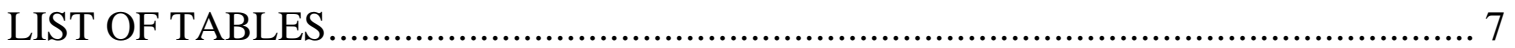

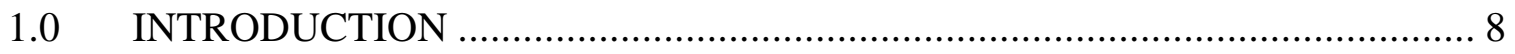

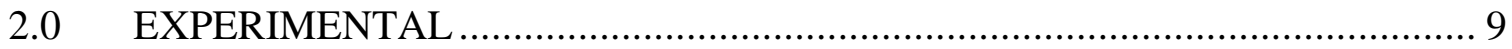

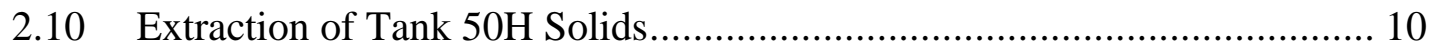

2.2 Plutonium and Neptunium Loading Curves on Sorbents .............................. 11

3.0 RESULTS AND DISCUSSION ......................................................... 14

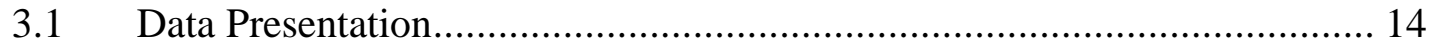

3.2 Physical Properties of Tank 50H Solids ................................................ 14

3.3 Investigation of Tank 50H Solids Interactions with Actinides ................... 15

3.4 Tank 50H Solid and Liquid Fraction Interactions with Actinides ............... 16

3.5 Single Component Tests for Tank 50H Solids ........................................... 18

3.6 Nitrated Cancrinite and Activated Carbon Interactions with the Actinides . 20

3.7 Iron Oxide and Sodium Phosphate Interactions with Actinides ...................... 21

3.8 Potassium Tetraphenylborate and Scintillation Cocktail Interactions with

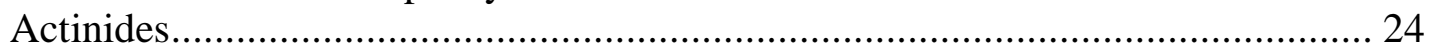

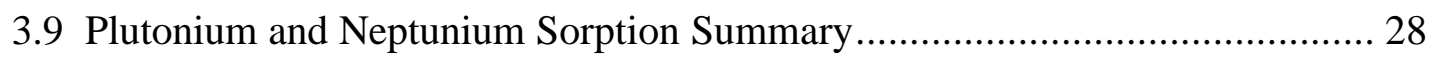

3.10 Plutonium and Neptunium Loading Curves with "Neat" ETF Carbons, Hematite, and Sodium phosphate. ................................................................................... 31

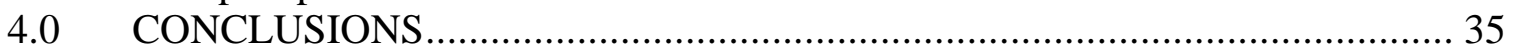

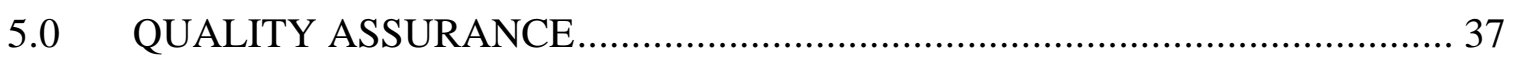

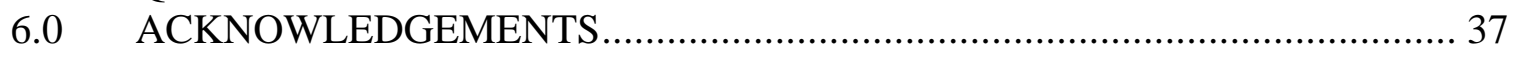

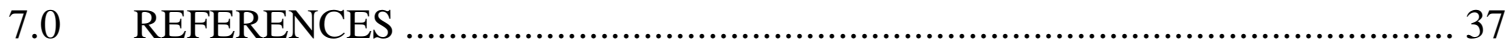

\section{LIST OF FIGURES}

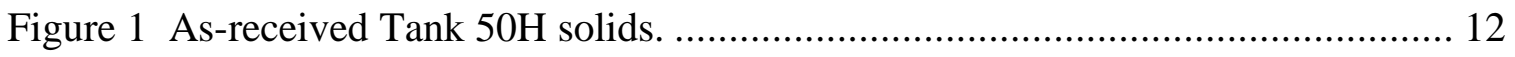

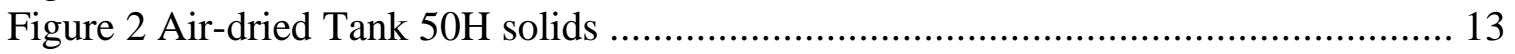

Figure 3. X-Ray Diffraction Powder Pattern of Air-dried Tank 50H Solids ................ 15

Figure 4. Effects of liquid-to-solid ratio on simulant solution actinide concentration in contact with Tank $50 \mathrm{H}$ solids. Plots at liquid-to-solid ratio of zero represent concentration of the actinides before contact. ................................................ 16

Figure 5. Actinide removal from contact with Tank 50H solid fraction. .................... 19

Figure 6 Changes in actinide concentration with time for nitrated cancrinite contacted with synthetic salt solution. ..................................................................... 22

Figure 7 Changes in actinide concentration with time for nitrated cancrinite contacted with synthetic salt solution.............................................................. 22

Figure 8 Changes in actinide concentration with time for new ETF activated carbon contacted with synthetic salt solution ........................................................ 23 
Figure 9 Changes in actinide concentration with time for Old ETF activated carbon contacted with synthetic salt solution. ...................................................... 24

Figure 10 Changes in actinide concentration with time for hematite contacted with

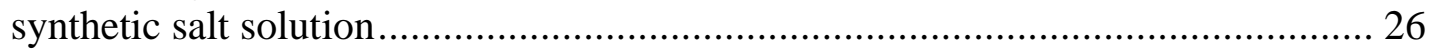

Figure 11 Changes in actinide concentration with time for sodium phosphate contacted

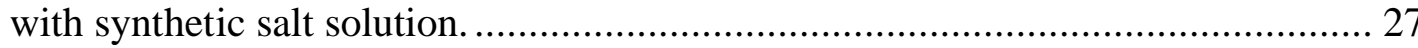

Figure 12 Neptunium and plutonium loading curves on Old ETF Activated carbon...... 32

Figure 13 Neptunium and plutonium loading curves on New ETF activated carbon..... 33

Figure 14 Neptunium and plutonium loading curves on hematite. ............................. 33

Figure 15 Neptunium and uranium loading curves on sodium phosphate..................... 34

\section{LIST OF TABLES}

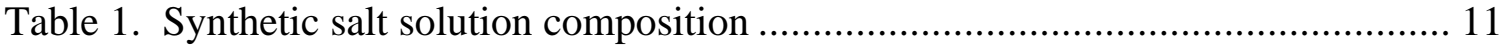

Table 2 Tank 50H components evaluated for removal of actinides ............................ 14

Table 3 Actinide concentration for Tank 50H liquid fraction.................................. 17

Table 4 Data summary for the interaction of actinides with potassium tetraphenylborate

Table 5 Data summary for the interaction of actinides with scintillation cocktail......... 28

Table 6 Plutonium and neptunium removed from synthetic salt solution per gram of sorbent after 24 hours contact...................................................................... 30

Table 7 Transition metal cation and Activated Carbon content in Tank 50H solids*..... 30

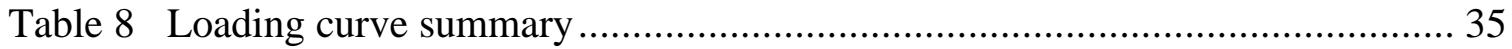




\subsection{INTRODUCTION}

Tank $50 \mathrm{H}$ is scheduled to return to HLW Tank Farm service with the capability to receive salt supernate solutions for feed to the Saltstone Facility. However, the presence of two large mounds ("North" and "South" mounds) of solid material ${ }^{1}$ in the tank presents a number of issues which have to be dealt with before Tank $50 \mathrm{H}$ can be returned to HLW service ${ }^{2}$. Charaterizations of the Tank $50 \mathrm{H}$ solids. ${ }^{3,4}$ indicated the presence of a significant fraction of sodium oxalate, scintillation cocktails, carbon black, cancrinite, sodium phosphate, tetraphenylborate and other yet unidentified materials in the north and south mound solids.

The final fate of decontaminated liquid waste at the Savannah River Site is to grout the liquid supernate for disposal in the Saltstone Facility. Here, the Tank 50H would serve as a staging tank and decontaminated supernate would be routinely transferred from Tank $50 \mathrm{H}$ to the Saltstone feed tank for processing. One option under consideration allows keeping the solids in Tank $50 \mathrm{H}$ and bringing low-curie salt solution, as planned, into the tank before sending on to Saltstone. An issue with this option is what effect, if any, the oxalate-rich and yet uncharacterized solids in the tank will have on the dissolved uranium and other actinides in the incoming salt solutions. The uncharacterized solids may dissolve and bring about the precipitation and accumulation of actinides such as uranium and plutonium. Since SRS wastes frequently contain enriched uranium and weaponsgrade plutonium, accumulation of the uranium and plutonium in a solid phase is a possible criticality safety concern.

Current activities under way to prepare the Tank $50 \mathrm{H}$ for service include dissolving the Tank $50 \mathrm{H}$ solids with "inhibited" water $(0.01 \mathrm{M} \mathrm{NaOH})$ and transferring to the Saltstone Facility for disposal. In these slurry processing activities an attempt will be made to remove all of the solid mounds present in Tank $50 \mathrm{H}$.

In a recent study ${ }^{4}$ to examine the effects of contacting a simulated salt solution spiked with uranium, plutonium and neptunium with Tank $50 \mathrm{H}$ solids, it was observed that both plutonium and neptunium were selectively removed from the salt solution in the presence of Tank $50 \mathrm{H}$ solids.

In this follow up study an attempt has been made to identify the Tank $50 \mathrm{H}$ solids components responsible for removing the actinides mentioned above. Identification of the plutonium-and neptunium-sorbing materials will help to assess whether the material is limited to Tank $50 \mathrm{H}$ or occurs widely in the HLW system.

Activated carbon and iron oxides are two of the many materials which have been identified as components of the Tank $50 \mathrm{H}$ solids. ${ }^{3}$ Based on plant history, the presence of activated carbon in the Tank Farm Waste storage system may be limited only to Tank $50 \mathrm{H}$, although other forms of carbon are certainly present in various storage tanks. Activated carbons, it is known, may have been introduced into the Tank $50 \mathrm{H}$ as a result of back flushing activities at the ETF carbon beds. In this process, the carbon fines end up as evaporator bottoms which are eventually transferred to the Tank 50H. Iron, on the other hand, exists in various oxidation forms, mostly in the $\mathrm{Fe}^{3+}$ and $\mathrm{Fe}^{2+}$ oxidation states. The usually amorphous and crystalline (mostly hematite and some magnetite) phases of iron minerals present in the tanks are known neutron "poisons". 
This report responds to Technical Task Request HLE-TTR-2003-068, Rev.1, which includes a task to identify the Tank $50 \mathrm{H}$ solids component materials responsible for plutonium and neptunium removal from simulated Tank $50 \mathrm{H}$ supernate salt solution. Three types of laboratory tests were performed: (1) separation of Tank $50 \mathrm{H}$ solids into insoluble and soluble fractions and testing each fraction for actinide removal efficiency, (2) single component tests with selected Tank $50 \mathrm{H}$ components and (3) tests to determine loading curves and the loading capacities for plutonium and neptunium using "neat" commercial materials of the identified actinide sorbents. The word "neat" as used here refers to the fact that the absorbing or precipitating solids which are some of the components of the Tank 50H solids, for example old Effluent Treatment Facility granular activated carbon (old ETF GAC), the new ETF millimeter-size activated carbon rods currently in use at the ETF or hematite (iron oxide), were used as-received from the various commercial sources.

\subsection{EXPERIMENTAL}

One Tank 50H core sample tube, labeled as HTF-E-03-17, was provided by the plant for this study. A photograph of the sampler and its contents is shown in Figure 1. Based on the orientation of the sample tube, three distinct sample sections with different water content and fluidity (labeled B, C, and D in Figure 1) were observed in the Tank $50 \mathrm{H}$ material used in this study. These three sections were blended together in a large polyethylene bottle and air dried in a hood for several hours until a fairly constant weight material was obtained. The resulting air-dried Tank $50 \mathrm{H}$ solid sample was used in this study (see Figure 2). The Tank 50H solids components evaluated for actinide (plutonium, neptunium and uranium) removal in the synthetic salt solution included the two forms of the ETF activated carbons, nitrated cancrinite, iron oxide (hematite), potassium tetraphenylborate, liquid scintillation cocktail and the Tank $50 \mathrm{H}$ solid and liquid fractions. Sodium phosphate, which is not a component of the Tank $50 \mathrm{H}$ solids, was evaluated only as a reference material for uranium removal from the salt solution.

The two forms of activated carbon, described above, were provided by Effluent Treatment Facility (ETF) personnel. The old ETF granular activated carbon (old ETF GAC) with a commercial brand identification name "C-200 GAC" was manufactured by Duratec International and the new ETF activated carbon currently used at the ETF, with a brand name "Nusorb GC-60-15 carbon", is manufactured by Nucon International, Inc. The iron oxide (hematite) was a Fisher Scientific company commercial product and the nitrated cancrinite was provided by Dr. J. A. Mensah from the University of South Australia. The potassium tetraphenylborate was precipitated from a solution of sodium tetraphenylborate (Alfa Aeser) by addition of potassium nitrate. The resulting solid precipitate was washed and vacuum-dried to constant weight over several days at room temperature. The liquid organic scintillation cocktail (Ultima Gold AB) consisting of linear alkylbenzenes, phenylxylylethane, and non-ionic surfactants and other emulsifiers is manufactured by ICN Biomedicals, Inc. of Costa Mesa, California. The anhydrous sodium orthophosphate used in this study was derived from hydrated sodium orthophosphate $\left(\mathrm{Na}_{3} \mathrm{PO}_{4} \cdot 12 \mathrm{H}_{2} \mathrm{O}\right)$ by heating of the hydrated salt in stainless steel beaker 
to above its boiling point for several hours. The resulting solid was then transferred to an oven and maintained at $120{ }^{\circ} \mathrm{C}$ for an hour before bringing it to room temperature in a desiccator.

Table 2 summarizes the different Tank $50 \mathrm{H}$ solids components ${ }^{3}$ evaluated for plutonium, uranium and neptunium removal. The $\mathrm{x}$-marks on the table indicate where the presence of a particular component caused the precipitation or loss of that actinide ( $>10 \%$ loss) in the simulant solution bearing uranium, plutonium and neptunium.

The composition of the 5.6 molar sodium salt solution (spiked with near saturation levels of uranium and plutonium) is presented in Table 1. This salt solution is comparable to that expected to pass through the Tank $50 \mathrm{H}$ in the near future in support of the low-curie salt program and over the longer term from the Salt Waste Processing Facility. The uranium, plutonium and neptunium concentrations in the simulant used for these studies were stable after preparation. The target concentrations for these actinides in the simulant were, respectively, 10.0, 0.20 and $0.50 \mathrm{mg} / \mathrm{L}$ with a $10 \%$ margin of error. Single, pretest analytical results for uranium, plutonium and neptunium concentrations in the simulant were 10.7, 0.192 and $0.496 \mathrm{mg} / \mathrm{L}$, respectively.

In general, in the single component tests, 5 grams of each Tank $50 \mathrm{H}$ solids component were contacted with the simulant solution. The conservative liquid-to-solid ratio (by weight) of 5 used for these tests was based on original estimates of solids in Tank $50 \mathrm{H}$ (61,000 gallons) and approximately 300,000 gallons of solution derived from the dissolution of 100,000 gallons of saltcake from Tank 41H. Other liquid-to-solid ratios, usually higher than 5, were used in tests where we had problems performing liquid-solid separations or where the component showed extensive precipitation of the actinides from solution. The tests were performed in $150-\mathrm{mL}$ capped polypropylene bottles. Agitation of the Tank $50 \mathrm{H}$ solids component (neat materials, for example, cancrinite or activated carbon) and simulant was achieved by placing the capped polypropylene bottles in an orbital shaker (Lab-line model C-760) maintained at 175 revolutions per minute. Aliquots were taken from each test bottle every 24 hours for up to four days and analyzed for plutonium and neptunium. After contact, samples were filtered through a 0.45 -micron nylon syringe filter disc to remove undissolved solids. The filtrate was acidified with 5.0 $\mathrm{M}$ nitric acid and the actinide concentrations determined by inductively coupled plasma mass spectrometry (ICP-MS). All tests were performed at $26 \pm 2{ }^{\circ} \mathrm{C}$, which was the bath water temperature in the orbital shaker. Tests with no added solids (simulant solutions only) were featured in each test set as controls for preparation errors, instrumental biases and unexpected removal mechanisms such as sorption with polypropylene bottle walls. The controls (untreated samples) were also subjected to the same separation and acid dilution techniques described above.

\subsection{Extraction of Tank 50H Solids}

In tests on Tank $50 \mathrm{H}$ solid and liquid fraction interactions with actinides, a sample of air-dried Tank $50 \mathrm{H}$ solid (50.14 g) was dissolved in $500 \mathrm{~mL}$ of Tank Farm inhibited water. The Tank Farm inhibited water had already been filtered through a 0.45 micron filter prior to use. The resulting slurry of filtered Tank Farm inhibited water and Tank $50 \mathrm{H}$ solids was agitated in an orbital shaker set at $175 \mathrm{rpm}$ overnight. After the agitation 
of the slurry for 24 hours, a 0.45 micron-filter retainer was used to separate the liquid from the solid fraction. The solid fraction was air dried to constant weight. This leaching of Tank $50 \mathrm{H}$ solids was repeated and the average weight of dry solids recovered and dried to constant weight was $25.03 \pm 0.04$ grams. The weight of the soluble fraction was then determined by difference $(50.14-25.03 \mathrm{~g})$. The solid fraction was analyzed for actinide and total carbon. A $10 \mathrm{ml}$ portion of the Tank $50 \mathrm{H}$ liquid fraction (leachate) was mixed with an equal volume of the simulant solution bearing actinides $(10 \pm 1 \mathrm{mg} / \mathrm{L}$ uranium, $0.20 \pm 0.02 \mathrm{mg} / \mathrm{L}$ plutonium and $0.50 \pm 0.05 \mathrm{mg} / \mathrm{L}$ neptunium). This sample was prepared in duplicate and the mixture agitated in an orbital shaker for 24 hours. A sample was pulled from the mixture after the 24 hours and analyzed for actinide concentrations. This test was performed with the Tank $50 \mathrm{H}$ liquid fraction to determine if the components of Tank $50 \mathrm{H}$ solid responsible for actinide removal were in the liquid/soluble phase of Tank $50 \mathrm{H}$ solids.

\subsection{Plutonium and Neptunium Loading on Sorbents}

In the loading curve tests each "neat" solid material under study was mixed with a specific volume of simulant solution at different liquid-to-solid ratios (generally, 14:1, 20:1, 24:1, 30:1, 40:1, 50:1 and 60:1). Seven liquid-to-solid ratio (volume/weight) samples were prepared with the weight of the neat solid test material maintained constant at either 0.25 or 0.5 grams. The eighth sample in each batch of tests was the plain simulant solution used as the control and contained no solids. A twenty-four hour shaking of the mixture in an orbital shaker at room temperature $\left(26 \pm 2{ }^{\circ} \mathrm{C}\right)$ was judged sufficient, based on previous experience ${ }^{4}$, for attainment of sorption equilibrium. After 24 hours of shaking, the liquid phase was separated from the solid phase using a 0.45 -micron nylon filter. A portion of the liquid fraction was diluted with 5.0 M nitric acid and analyzed for plutonium and neptunium. The control sample was processed similarly including filtration and acid dilution. Apart from runs involving sodium phosphate, the sample solutions were not analyzed for uranium since previous tests showed that none of the "neat" materials were found to remove significant amounts of uranium.

Table 1. Synthetic salt solution composition

\begin{tabular}{|c|c|c|}
\hline Component & Target concentration & Units \\
\hline Total $\mathrm{Na}$ & 5.60 & $\mathrm{M}$ \\
\hline Free $\mathrm{NaOH}$ & $1.33 \mathrm{E}+00$ & $\mathrm{M}$ \\
\hline $\mathrm{NaNO}_{3}$ & $2.60 \mathrm{E}+00$ & $\mathrm{M}$ \\
\hline $\mathrm{NaNO}_{2}$ & $1.64 \mathrm{E}-01$ & $\mathrm{M}$ \\
\hline $\mathrm{Na}_{2} \mathrm{SO}_{4}$ & $5.21 \mathrm{E}-01$ & $\mathrm{M}$ \\
\hline $\mathrm{Na}_{2} \mathrm{CO}_{3}$ & $2.60 \mathrm{E}-02$ & $\mathrm{M}$ \\
\hline $\mathrm{NaAl}(\mathrm{OH})_{4}$ & 4.29E-01 & $\mathrm{M}$ \\
\hline Total U & $10.0 \pm 1$ & $\mathrm{mg} / \mathrm{L}$ \\
\hline Total Pu & $0.20 \pm 0.02$ & $\mathrm{mg} / \mathrm{L}$ \\
\hline $\mathrm{Np}-237$ & $0.50 \pm 0.050$ & $\mathrm{mg} / \mathrm{L}$ \\
\hline
\end{tabular}


WSRC-TR-2003-00554, Rev. 0

Page 12 of 38

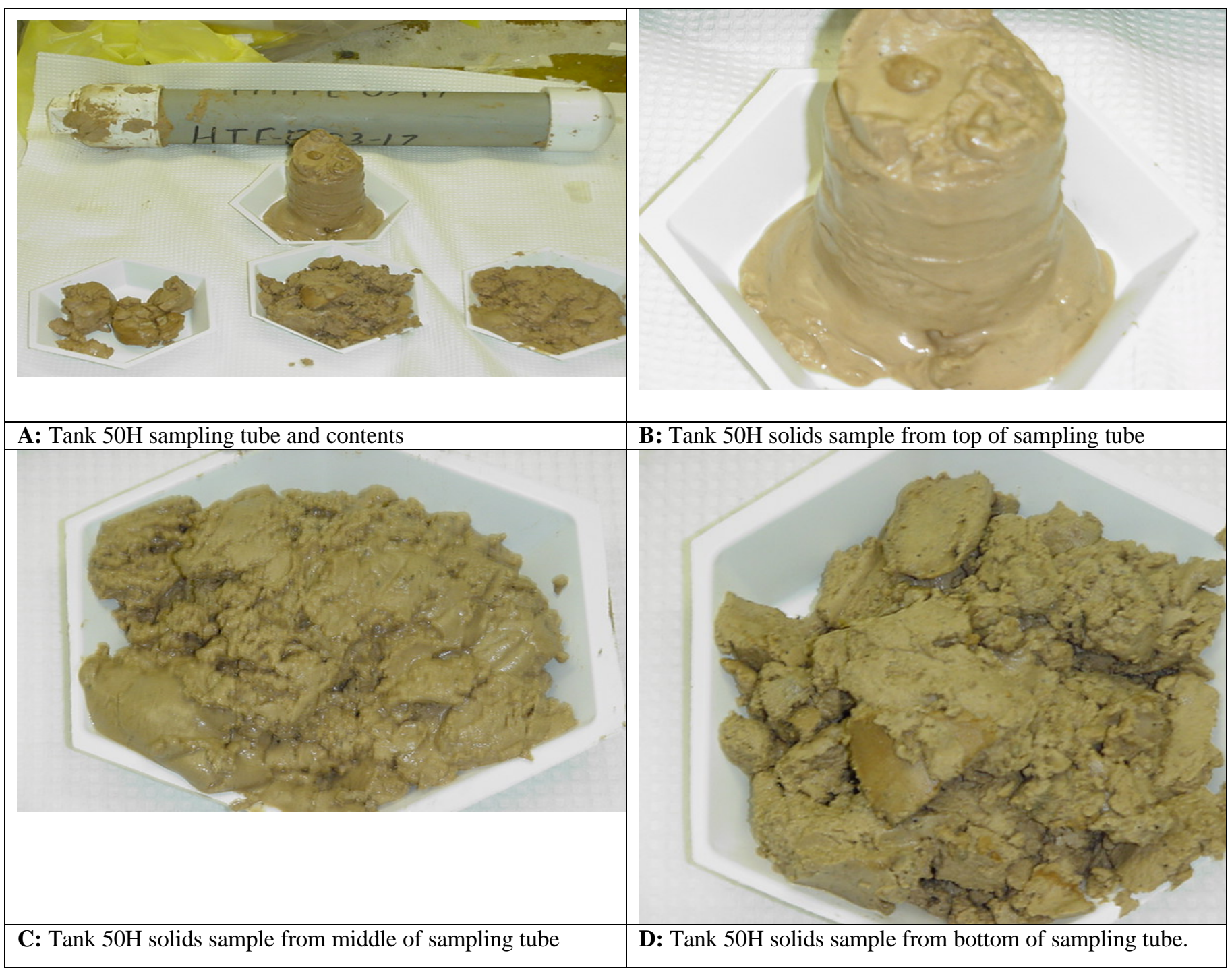

Figure 1 As-received Tank $50 \mathrm{H}$ solids. 
WSRC-TR-2003-00554, Rev. 0

Page 13 of 38

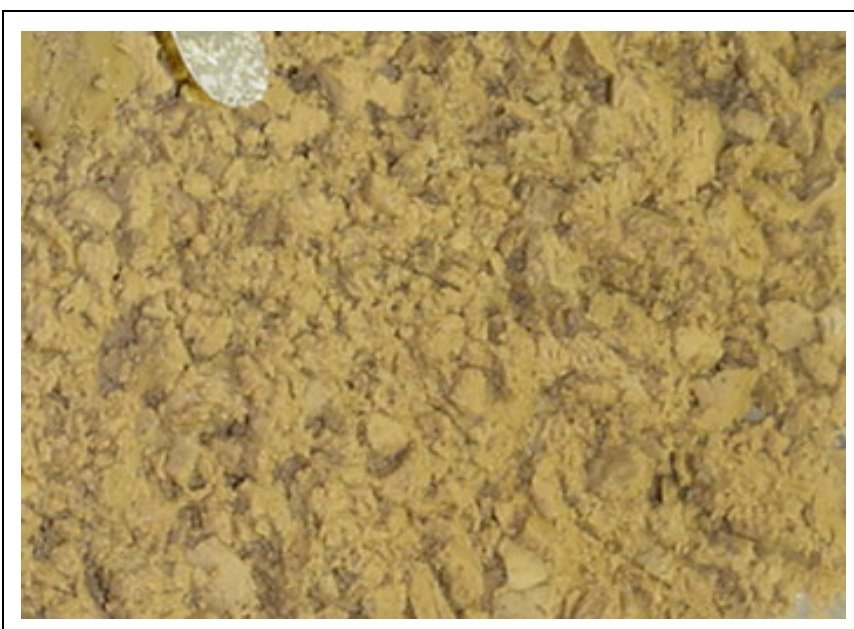

Blend of samples A, B and C: After 72-hour hood exposure

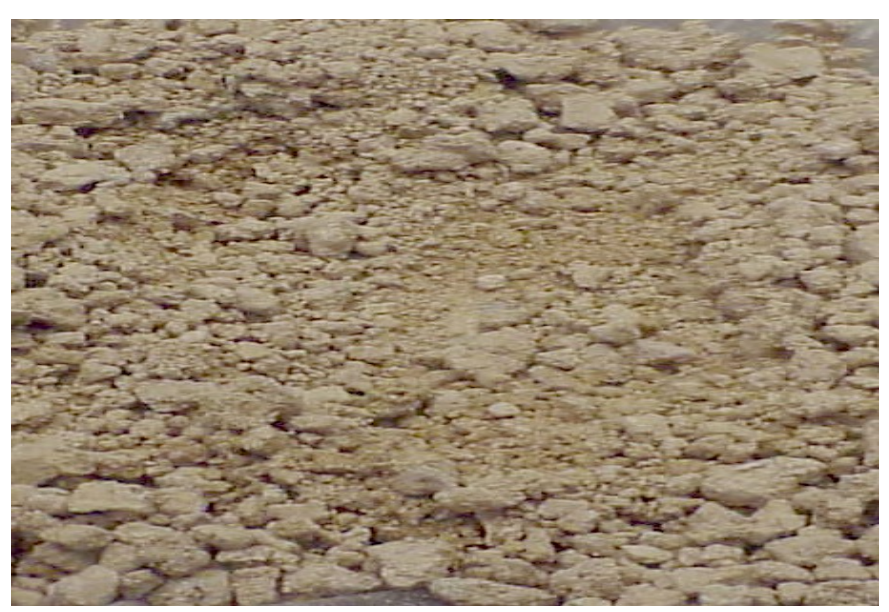

Blend of samples A, B and C: After 264- hours hood exposure

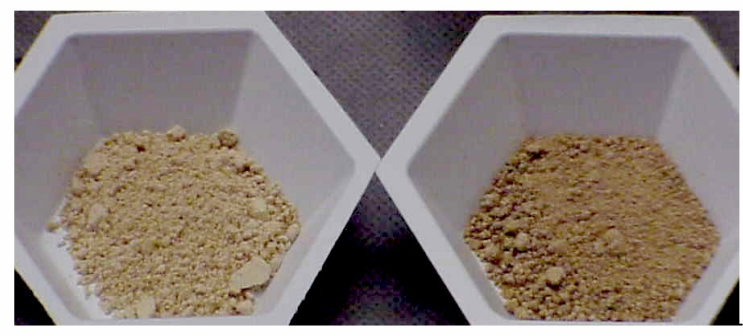

\section{BLANK}

Current Tank $50 \mathrm{H}$ solids (Left) and previous Tank $50 \mathrm{H}$ solids (Right). Differences in color may be due to differences in aging.

Figure 2 Air-dried Tank 50H solids 
Table 2 Tank 50H components evaluated for removal of actinides

\begin{tabular}{|c|c|c|c|c|}
\hline Component & Uranium & Plutonium & Neptunium & Comments \\
\hline \multicolumn{5}{|l|}{ Nitrated Cancrinite } \\
\hline Activated Carbon & & $\mathrm{X}$ & $\mathrm{X}$ & \\
\hline & & & & \\
\hline Iron Oxide (hematite) & & $\mathrm{X}$ & $\mathrm{X}$ & \\
\hline Sodium phosphate & $\mathrm{X}$ & & $\mathrm{X}$ & Reference; not a Tank 50H component \\
\hline \multicolumn{5}{|l|}{ Potassium tetra phenyl borate } \\
\hline Sodium oxalate & & & & From previous study see reference 4 \\
\hline & & & & \\
\hline \multicolumn{5}{|l|}{ Scintillation Cocktail } \\
\hline \multicolumn{5}{|l|}{ Control (no added component) } \\
\hline Tank 50H solids & & $\mathrm{X}$ & $\mathrm{X}$ & \\
\hline $\begin{array}{l}\text { Tank } 50 \mathrm{H} \text { solid fraction derived } \\
\text { by leaching with Plant inhibited } \\
\text { water }\end{array}$ & & $\mathrm{X}$ & $\mathrm{X}$ & \\
\hline $\begin{array}{l}\text { Tank } 50 \mathrm{H} \text { liquid fraction derived } \\
\text { by leaching with Plant inhibited } \\
\text { water }\end{array}$ & & & & \\
\hline
\end{tabular}

Here $\mathrm{X}$ indicates precipitation or loss of that actinide in the presence of that Tank $50 \mathrm{H}$ component.

\subsection{RESULTS AND DISCUSSION}

\subsection{Data Presentation}

Graphically, the experimental results are presented here in three ways: (1) Changes in actinide concentrations with contact or exposure time in the presence of sorbents, (2) actinide concentration changes at different liquid-to-solid ratios, and (3) loading curves for actinides and strontium in the presence of the precipitating agent ("neat" sorbent) at different liquid-to-solid ratios.

\subsection{Physical Properties of Tank 50H Solids}

The air-dried Tank $50 \mathrm{H}$ solid sample produced the x-ray diffraction pattern shown in Figure 3. The pattern exhibits sharp diffraction peaks and a smooth baseline indicative of a very crystalline material. Three crystalline materials were identified in the air-dried Tank $50 \mathrm{H}$ sample: sodium oxalate $\left(\mathrm{Na}_{2} \mathrm{C}_{2} \mathrm{O}_{4}\right)$, strontium oxalate, and calcium oxalate hydrate $\left((\mathrm{COO})_{2} \mathrm{Ca} \cdot \mathrm{H}_{2} \mathrm{O}\right)$. An unassigned peak at $(2 \Phi=140)$ suggests the presence of additional unidentified crystalline material. The x-ray pattern obtained for the current Tank $50 \mathrm{H}$ solids is in fairly good agreement with other similar Tank $50 \mathrm{H}$ solids ${ }^{3}$ (Question marks,?, on XRD spectra indicate unmatched or unidentified peaks). 
Aqua regia digestion of air-dried Tank $50 \mathrm{H}$ solid was followed by analysis for uranium using inductively-coupled plasma atomic emission spectrometer (ICP-ES). ICP-ES analysis for uranium gave a uranium concentration of $0.217 \pm 0.011 \mathrm{mg}$ uranium per gram of Tank $50 \mathrm{H}$ solid. Previous characterization of Tank $50 \mathrm{H}$ solids gave an average value of $0.365 \pm 0.030 \mathrm{mg}$ uranium per gram of Tank $50 \mathrm{H}$ solids ${ }^{4}$. Total carbon analysis for air-dried Tank $50 \mathrm{H}$ solids gave a value of $135 \mathrm{mg}$ carbon per gram of air-dried Tank $50 \mathrm{H}$ solids (13.5\% carbon). This value is in agreement with values reported earlier on Tank $50 \mathrm{H}$ solids ${ }^{3,4}$.

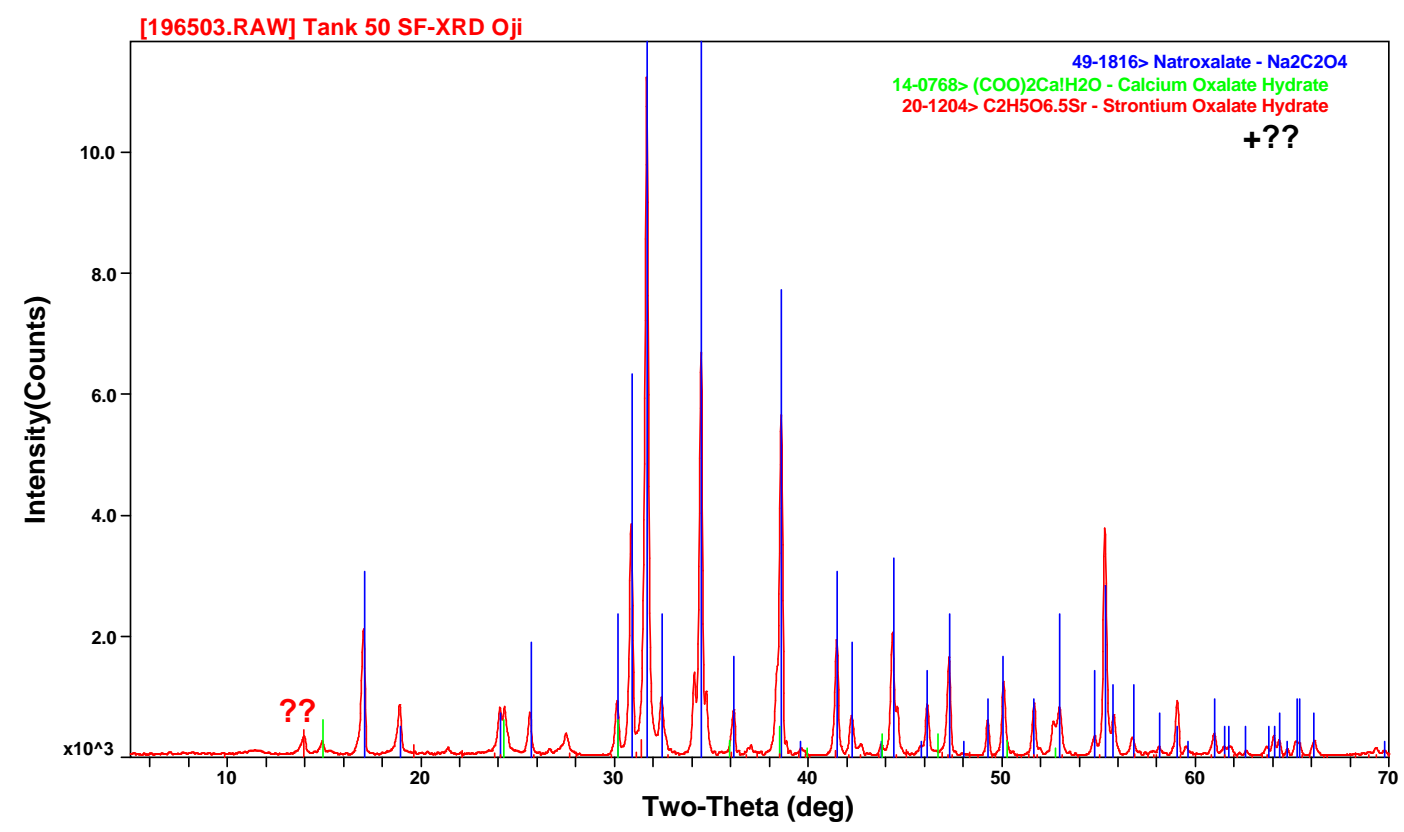

Figure 3. X-Ray Diffraction Powder Pattern of Air-dried Tank 50H Solids .

\subsection{Investigation of Tank 50H Solids Interactions with Actinides}

The air-dried Tank $50 \mathrm{H}$ solids were contacted with salt solution containing uranium, plutonium and neptunium. Plots in Figure 4 show actinide concentrations after 24-hour contact for a range of liquid-to-solid ratios. The selections of 24-hour contact time was based on previous study with Tank $50 \mathrm{H}$ solids (reference 4), which showed that this was sufficient contact time for the sorption of actinides onto Tank $50 \mathrm{H}$ solids in the stimulant solution.

No significant changes in uranium concentration occurred over the 24-hour contact time when air-dried Tank $50 \mathrm{H}$ solids were contacted with the synthetic salt solution. Plutonium and neptunium were removed from the simulant solution in the presence of the 
air-dried Tank $50 \mathrm{H}$ solids. These results are consistent with earlier study with Tank $50 \mathrm{H}$ solids as presented in reference 4 .

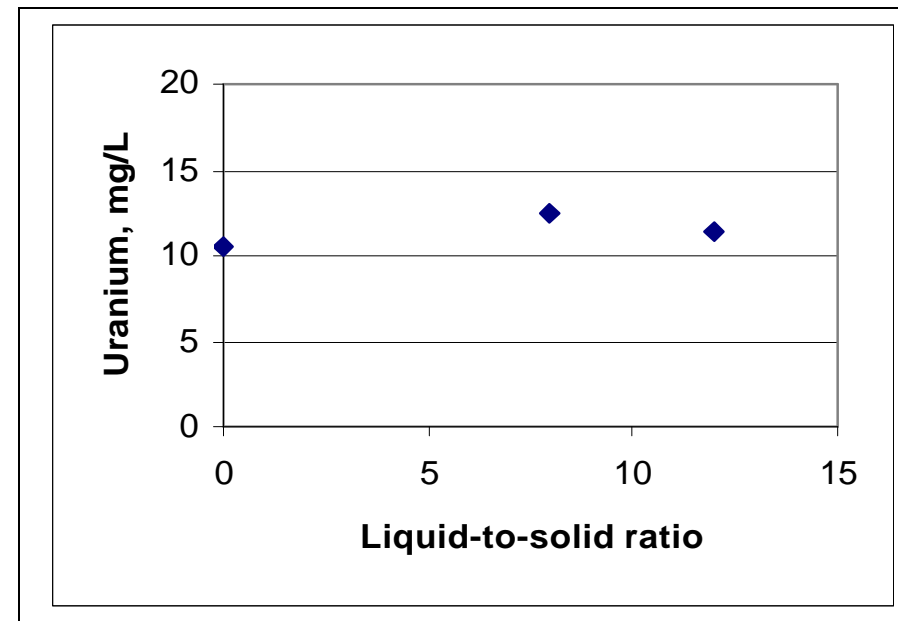

A: Uranium is not removed from simulant in the presence of Tank $50 \mathrm{H}$ solids

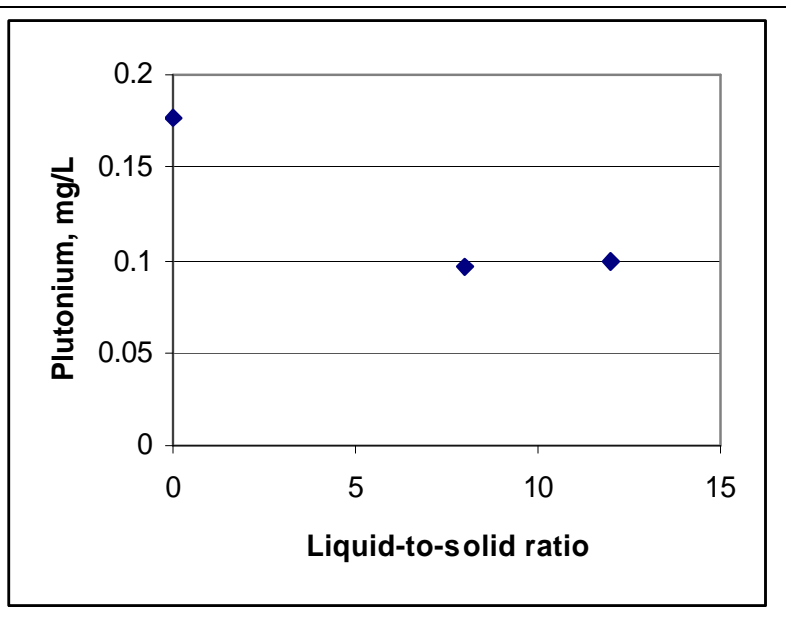

B: Plutonium is removed in the presence of Tank $50 \mathrm{H}$ solids

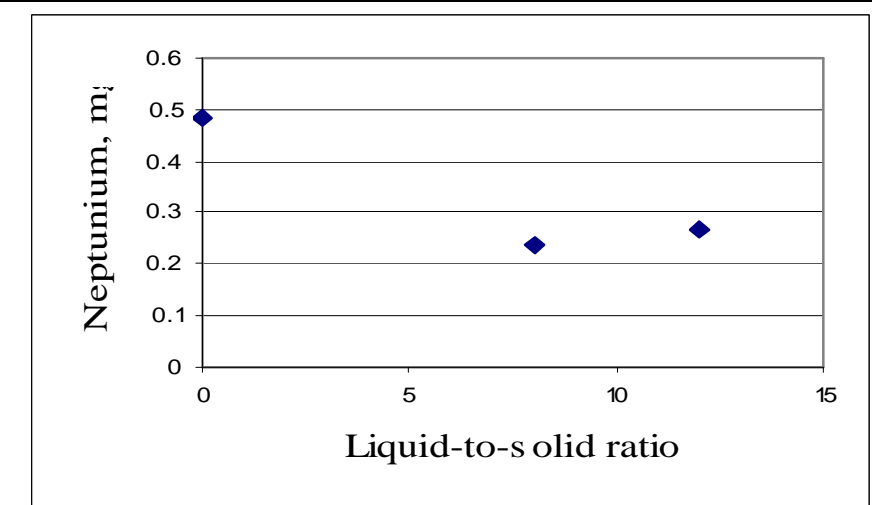

C: Neptunium is removed in the presence of Tank $50 \mathrm{H}$ solids

Figure 4. Effects of liquid-to-solid ratio on simulant solution actinide concentration in contact with Tank 50H solids. Plots at liquid-to-solid ratio of zero represent concentration of the actinides before contact.

\subsection{Tank 50H Solid and Liquid Fraction Interactions with Actinides}

As described earlier, air-dried Tank $50 \mathrm{H}$ solids were leached with plant inhibited water, yielding an undissolved solid fraction and a liquid fraction. The solid fraction was airdried. Analysis of the initial plant inhibited water showed that no actinides or any other radionuclides were present. An equal volume of this Tank $50 \mathrm{H}$ liquid fraction and the simulant solution bearing actinides were mixed, agitated and sampled for actinide analysis after 24 hours. Analysis of the filtrate, as summarized in Table 3, shows that there was more uranium, plutonium and neptunium in the Tank $50 \mathrm{H}$ soluble fraction than in the original simulant. The uranium, plutonium and neptunium concentrations in the mixture averaged $53.4 \pm 12.3,0.70 \pm 0.18$ and $1.85 \pm 0.5 \mathrm{mg} / \mathrm{L}$, respectively. Since there 
were no radionuclides detected in the plant inhibited water, it can be concluded that the increase in actinide concentrations was due to the presence of Tank $50 \mathrm{H}$ soluble fraction.

Based on calculations shown below the actual uranium, plutonium and neptunium contributions from the Tank $50 \mathrm{H}$ liquid fraction were, respectively, 97, 1.2 and $3.2 \mathrm{mg} / \mathrm{L}$.

$\{10 \mathrm{ml}$ of simulant solution $+10 \mathrm{ml}$ of Tank $50 \mathrm{H}$ liquid fraction

$\mathrm{U}, \mathrm{Pu}$ and $\mathrm{Np}$ concentration in simulant are, respectively, in 10, 0.2 and $0.5 \mathrm{mg} / \mathrm{L}$

\section{For Np}

$(0.01 \mathrm{~L})(0.5 \mathrm{mg} / \mathrm{L})+(0.01 \mathrm{~L}) * \mathrm{X}=(1.85 \mathrm{mg} / \mathrm{L})^{*} 0.02 \mathrm{~L}$

$0.01 L^{*} X=0.037 \mathrm{mg}-0.005 \mathrm{mg}$

$X=3.2 \mathrm{mg} / \mathrm{L}$

For $\mathrm{Pu}$

$\overline{(0.01 \mathrm{~L})}(0.2 \mathrm{mg} / \mathrm{L})+(0.01 \mathrm{~L}) * \mathrm{X}=(0.7 \mathrm{mg} / \mathrm{L}) * 0.02 \mathrm{~L}$

$0.01 L^{*} X=0.014 \mathrm{mg}-0.002 \mathrm{mg}$

$X=1.2 \mathrm{mg} / \mathrm{L}$

For U

$(0.01 \mathrm{~L})(10 \mathrm{mg} / \mathrm{L})+(0.01 \mathrm{~L}){ }^{*} \mathrm{X}=(53.42 \mathrm{mg} / \mathrm{L}) * 0.02 \mathrm{~L}$

$0.01 \mathrm{~L}^{*} \mathrm{X}=1.068 \mathrm{mg}-0.1 \mathrm{mg}$

$\mathrm{X}=96.84 \mathrm{mg} / \mathrm{L}\}$

Without further characterization and comparing of the Tank $50 \mathrm{H}$ liquid fraction and the original air-dried Tank $50 \mathrm{H}$ solids, it is not possible to conclude there was a measurable loss of the actinides from the mixture as a result of blending the simulant solution with the Tank $50 \mathrm{H}$ liquid fraction. Hence, although the test results so far performed with the Tank $50 \mathrm{H}$ solids materials will seem to suggest that the components of the Tank $50 \mathrm{H}$ solids responsible for the removal of actinides from solution are in the solid fraction of the Tank $50 \mathrm{H}$ solids, one can not say with great certainty that some soluble components like organic complexes in the liquid fraction do not contribute to the removal of actinides.

Aqua regia digestion of the Tank $50 \mathrm{H}$ solid fraction in triplicate followed by ICP-ES analysis for uranium gave a uranium concentration of $0.33 \pm 0.06 \mathrm{mg}$ uranium per gram of Tank $50 \mathrm{H}$ solid fraction. Total carbon analysis for Tank $50 \mathrm{H}$ solid fraction gave a value of $144 \mathrm{mg}$ carbon per gram of Tank $50 \mathrm{H}$ solids (14.4\% carbon). These values for the uranium and carbon content are consistent with previous characterizations of the Tank $50 \mathrm{H}$ solids where these values were, respectively, reported as $0.37 \pm 0.03$ and $13.5 \% .^{3,4}$

Table 3 Actinide concentration for Tank $50 \mathrm{H}$ liquid fraction

\begin{tabular}{|l|c|c|c|}
\hline & $\mathbf{U}, \mathbf{~ m g / L}$ & $\mathbf{P u}, \mathbf{~ m g} / \mathbf{L}$ & $\mathbf{N p}, \mathbf{~ m g} / \mathbf{L}$ \\
\hline Concentration in simulant & $10.0 \pm 1.0$ & $0.2 \pm 0.02$ & $0.50 \pm 0.05$ \\
\hline & & & \\
\hline $\begin{array}{l}\text { Measured concentration in the } \\
\text { mixture after contact }\end{array}$ & $53.4 \pm 12.3$ & $0.70 \pm 0.18$ & $1.85 \pm 0.46$ \\
\hline $\begin{array}{l}\text { Calculated concentration in } \\
\text { Tank 50H liquid fraction }\end{array}$ & 97 & 1.2 & 3.2 \\
\hline
\end{tabular}


Figure 5, inserts $\mathrm{A}$ through $\mathrm{F}$, shows the change in actinide concentrations with time for simulant solutions contacted with the Tank $50 \mathrm{H}$ solid fraction (undissolved solids from leaching with plant inhibited water). The tests were performed at two simulant-to-solid ratios of 25:1 and 8:1. In Figure 5, the changes in actinide concentration with time are presented in inserts $\mathrm{A}, \mathrm{C}$ and $\mathrm{E}$ and the changes in actinide concentration with variation in liquid-to-solid ratios are presented in Figure 5 inserts B, D and F.

There was no measurable difference in uranium concentrations before and after contacting of the simulant with Tank $50 \mathrm{H}$ solid fraction after for more than 72 hours (Figure 5 insert A). The uranium concentration in the post-contact Tank $50 \mathrm{H}$ solid fraction averaged $10.6 \pm 0.6 \mathrm{mg} / \mathrm{L}$ and is not statistically different from the original uranium concentration in the simulant before contact $(10.6 \pm 1.0 \mathrm{mg} / \mathrm{L})$.

Removal of uranium, even at lower liquid-to-solid ratio was not observed (Figure 5 insert B). Only plutonium and neptunium removed from solution in the presence of Tank $50 \mathrm{H}$ solid fraction (Figure 5 inserts C, D, E and F). After 72 hours contact, the soluble plutonium concentration in the mixture had dropped to below instrument detection level (Figure 5 insert $\mathrm{C}$ ) and the neptunium concentration had dropped to less than $50 \%$ of its original concentration in the simulant (Figure 5 insert E). The decrease in plutonium and neptunium concentration with decrease in liquid to solid ratios as shown in Figure 5 inserts D and F, respectively, confirms the existence of a typical sorption phenomenon in the mixture. These observations are similar to the results obtained when the simulant solution was exposed to unleached Tank $50 \mathrm{H}$ solids (Figure 4), again confirming that the components responsible for the removal of actinides are in the Tank $50 \mathrm{H}$ solid fraction.

\subsection{Single Component Tests for Tank 50H Solids}

As already described and detailed in Table 2, the identified components of Tank $50 \mathrm{H}$ solids are nitrated cancrinite, activated carbon derived from ETF processes, scintillation cocktail, sodium oxalate and potassium tetraphenylborate. The changes in color of the wet Tank $50 \mathrm{H}$ solids from bright yellow paste to reddish-brown granules for the dry Tank $50 \mathrm{H}$ solids (Figures 1 and 2 ), suggests that Tank $50 \mathrm{H}$ solids contain a chromophore which causes such color changes with exposure to air following the loss of moisture. Based on plant history and chemistry of plant solids like the sludge, one of the possible chromophore candidates for the Tank $50 \mathrm{H}$ solids is iron which can exist in several oxidation states. The changes in color of the Tank $50 \mathrm{H}$ solids with exposure to air could be attributed to the existence of iron oxides, possibly hematite and magnetite $\left(\mathrm{Fe}_{3} \mathrm{O}_{4}\right)$. As a result, it was decided to include hematite (ferric oxide- $\mathrm{Fe}_{2} \mathrm{O}_{3}$ ) as one of the test components in this evaluation of components responsible for precipitation of plutonium and neptunium in simulant salt solution. Anhydrous sodium phosphate was also included in the test matrix because it is known to remove uranium. 
WSRC-TR-2003-00554, Rev. 0

Page 19 of 38

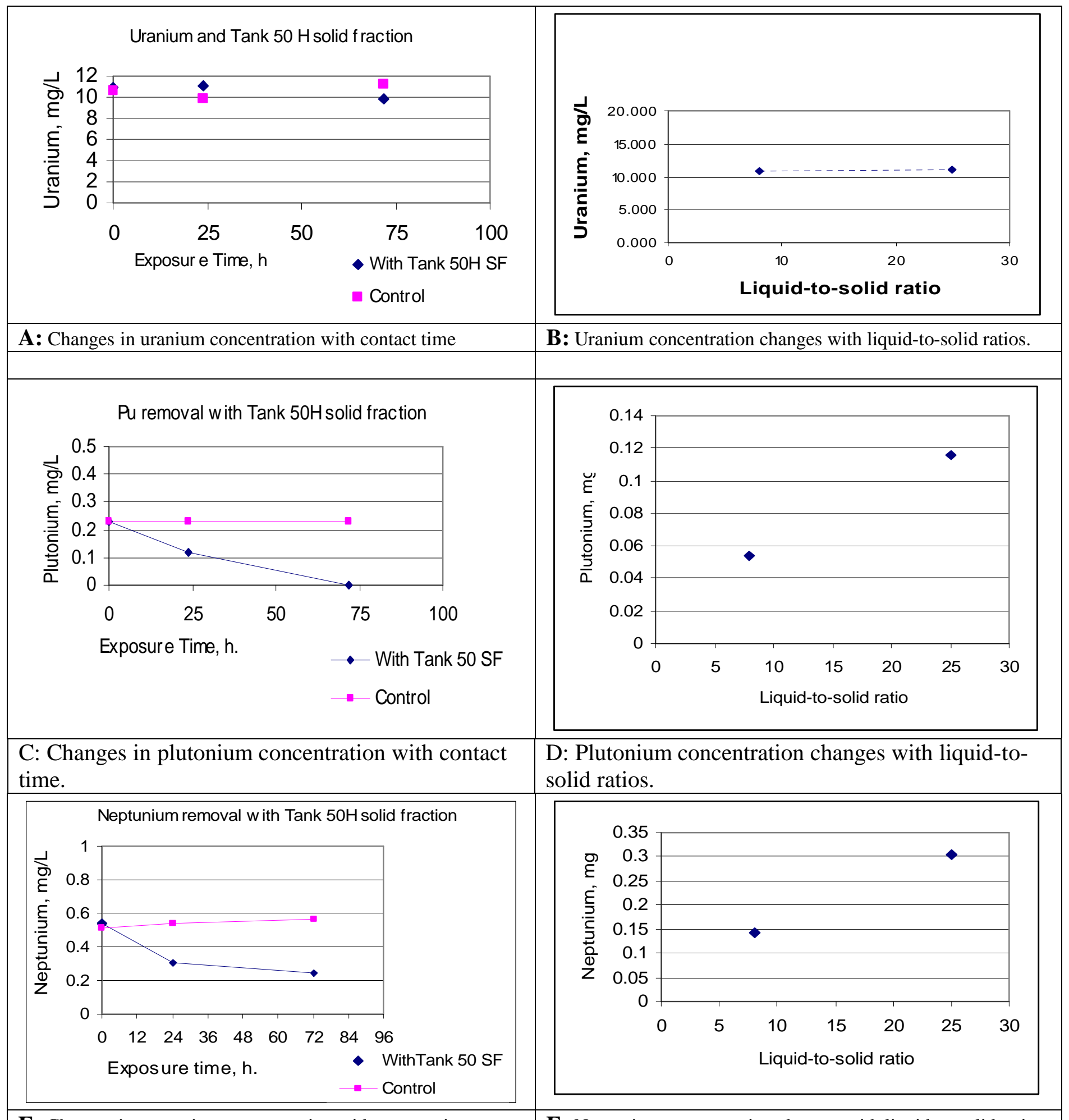

E: Changes in neptunium concentration with contact time.

F: Neptunium concentration changes with liquid-to-solid ratios.

Figure 5. Actinide removal from contact with Tank $50 \mathrm{H}$ solid fraction. 
WSRC-TR-2003-00554, Rev. 0

Page 20 of 38

\subsection{Nitrated Cancrinite and Activated Carbon Interactions with the Actinides}

The data presented here for nitrated cancrinite and the activated carbons are based on the 24-, 48- and 72-hour samples for cancrinite and new ETF activated carbons and 24-and 48-hour samples for the old ETF GAC.

Since cancrinite, an aluminosilicate, is a significant component of the Tank $50 \mathrm{H}$ solids, the cancrinite tests were run several times at different liquid-to-solid ratios to ensure that there was no significant removal of actinides within the first 24 hours of contact with simulant solution. The tests with nitrated cancrinite in the 5:1 ratio posed a special problem when separating the liquid from the solid fraction at the end of 24 hours. At this ratio, the resulting mixture formed a thick slurry after mixing and could not be filtered through 0.45 micron filtration discs. A staged filtration technique involving initial filtration with 1.0 micron filter disc followed by 0.45 micron discs was used to overcome this problem. In this initial 24-hour cancrinite test, about $85 \%$ of the neptunium and $78 \%$ of the plutonium was recovered. Over $95 \%$ of the uranium was recovered. The 24-hour $5: 1$ simulant-to-cancrinite ratio test was repeated three times using staged filtration. Over $95 \%$ of the initial neptunium, plutonium and uranium concentrations were recovered in each repeat test. Figure 6 includes the results of the 24-hour repeat tests, along with additional data at other time increments. The additional cancrinite tests used higher simulant-to-cancrinite ratios (25:1). At the higher ratio, filtration was easier and more than $95 \%$ of each of the actinides in all cases was recovered. Since the repeat tests and higher ratio tests did not result in any measurable loss of the actinides, we conclude that the apparent loss of neptunium and plutonium in the initial phase of the cancrinite tests was likely due to sampling or analytical errors.

The average uranium, plutonium and neptunium recovered in the control tests were 10.4 $\pm 0.5,0.20 \pm 0.03$ and $0.51 \pm 0.04 \mathrm{mg} / \mathrm{L}$, respectively. The average uranium, plutonium and neptunium recovered in the cancrinite in contact with simulant tests, at 5:1 ratio, were $10.17 \pm 0.29,0.20 \pm 0.01$ and $0.51 \pm 0.01$, respectively. Figures 6 and 7 summarize the post-contact results for nitrated cancrinite in the actinide-bearing simulant. Since the average actinide recovered after contact is not statistically different from the actinide concentrations in the controls, we conclude that nitrated cancrinite does not actively precipitate uranium, plutonium or neptunium from the synthetic salt solution (Figures 6 and 7).

Two forms of ETF activated carbon were used in these tests. Neither form affected uranium concentration; both forms removed neptunium and plutonium from the simulant salt solution (Figures 8 and 9). At the end of the first 24-hour sampling period, the new ETF activated carbon removed about $72 \%$ of the neptunium and more than $95 \%$ of the plutonium. Similarly, at the end of 24 hours, the old ETF GAC removed neptunium and plutonium in the simulant below instrument detection level (more than 95\%). When the amount of uranium recovered from contacting the new ETF activated carbon with simulant solution is compared ( 2 sigma) with the uranium in the controls $(10.5 \pm 0.3)$, there are no measurable losses of uranium due to the presence of the two types of activated carbon (Figures 8 and 9, inserts A). The average uranium recovered in the new 
ETF activated carbon in contact with simulant is $10.4 \pm 0.4$ and for the old ETF GAC in contact with simulant is $9.62 \pm 0.08$. The old ETF GAC removed less than $10 \%$ of the uranium in the salt solution.

Based on these test results, it is concluded that nitrated cancrinite in contact with simulant solution containing uranium, plutonium and neptunium does not show any measurable tendency to remove these actinides from solution. On the other hand, the two forms of activated carbon investigated in these tests show measurable affinity to remove plutonium and neptunium from solution. The new ETF activated carbon did not remove any measurable amount of uranium from the simulant solution, while the old ETF GAC removed less than $10 \%$ of the uranium. From plant history and process knowledge, the activated carbon in the Tank $50 \mathrm{H}$ solids used in this study is the old ETF carbon and not the new ETF activated carbon materials used by ETF.

\subsection{Iron Oxide and Sodium Phosphate Interactions with Actinides}

Figure 10, inserts $\mathrm{A}$ through $\mathrm{F}$ and Figure 11 shows the graphical presentation of the results obtained with the exposure of simulant solutions to "neat" hematite for up to 48 hours. In Figure 10, the changes in actinide concentration with time for these actinides are presented in inserts $\mathrm{A}, \mathrm{C}$ and $\mathrm{E}$ and the changes in concentration with variation in liquid-to-solid ratios are presented in Figure 10 inserts B, D and F. The changes in actinide concentration with exposure time were based on a liquid-to-solid (hematite) ratio of 50:1, while changes in actinide concentration with liquid-to-solid (hematite) ratio were based on three ratios: 5:1, 10:1 and 50:1.

Statistically, there were no measurable differences in uranium concentration when the simulant was contacted with hematite for 48 hours (Figure 10 inserts A and B). The uranium recovered from the interaction of the simulant solution with hematite averaged $10 \pm 0.4 \mathrm{mg} / \mathrm{L}$ compared to an average value of $10.4 \pm 0.3 \mathrm{mg} / \mathrm{L}$ for the untreated simulant. Precipitation of uranium, even at lower liquid-to-solid ratio (more hematite in contact with simulant), was not observed (Figure 10 insert B).

Plutonium and neptunium concentrations in solution decreased in the presence of hematite (Figure 10 inserts C, D, E and F). Within 24 hours of contacting hematite with the plutonium bearing simulant solution, the plutonium concentration dropped to an equilibrium level of about $0.07 \mathrm{mg} / \mathrm{L}$ compared to the initial concentration of $0.2 \mathrm{mg} / \mathrm{L}$. This was more than a $60 \%$ drop in plutonium concentration after contact with hematite (Figure 10 insert C). Similarly, the neptunium concentration in the hematite-contacted simulant dropped to less than $50 \%$ of its original concentration within 48 hours of contact (Figure 10 insert E). Figure 10, inserts $\mathrm{D}$ and $\mathrm{F}$ shows the effect of changing the simulant-to-solid ratio. In both overlay plots, as the simulant-to-solid ratios decrease (increase in hematite solid fraction) the amount of plutonium and neptunium removed from the liquid phase increased. This behavior is consistent with typical sorption suggesting that plutonium and neptunium are sorbing onto the hematite (iron oxides). 
WSRC-TR-2003-00554, Rev. 0

Page 22 of 38

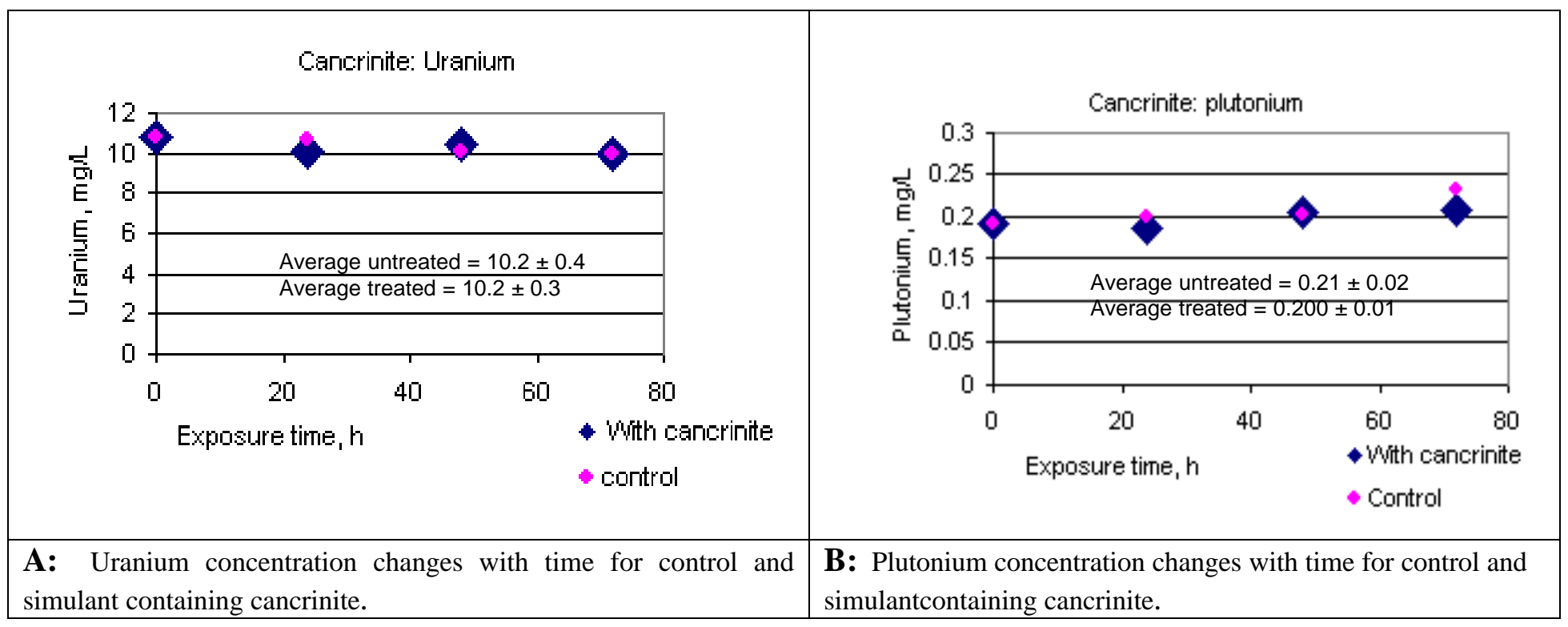

Figure 6 Changes in actinide concentration with time for nitrated cancrinite contacted with synthetic salt solution.

\begin{tabular}{|l|l|l|}
\hline & \\
\hline & & \\
\hline & Average untreated $=0.51+0.02$ \\
\hline
\end{tabular}

Figure 7 Changes in actinide concentration with time for nitrated cancrinite contacted with synthetic salt solution. 


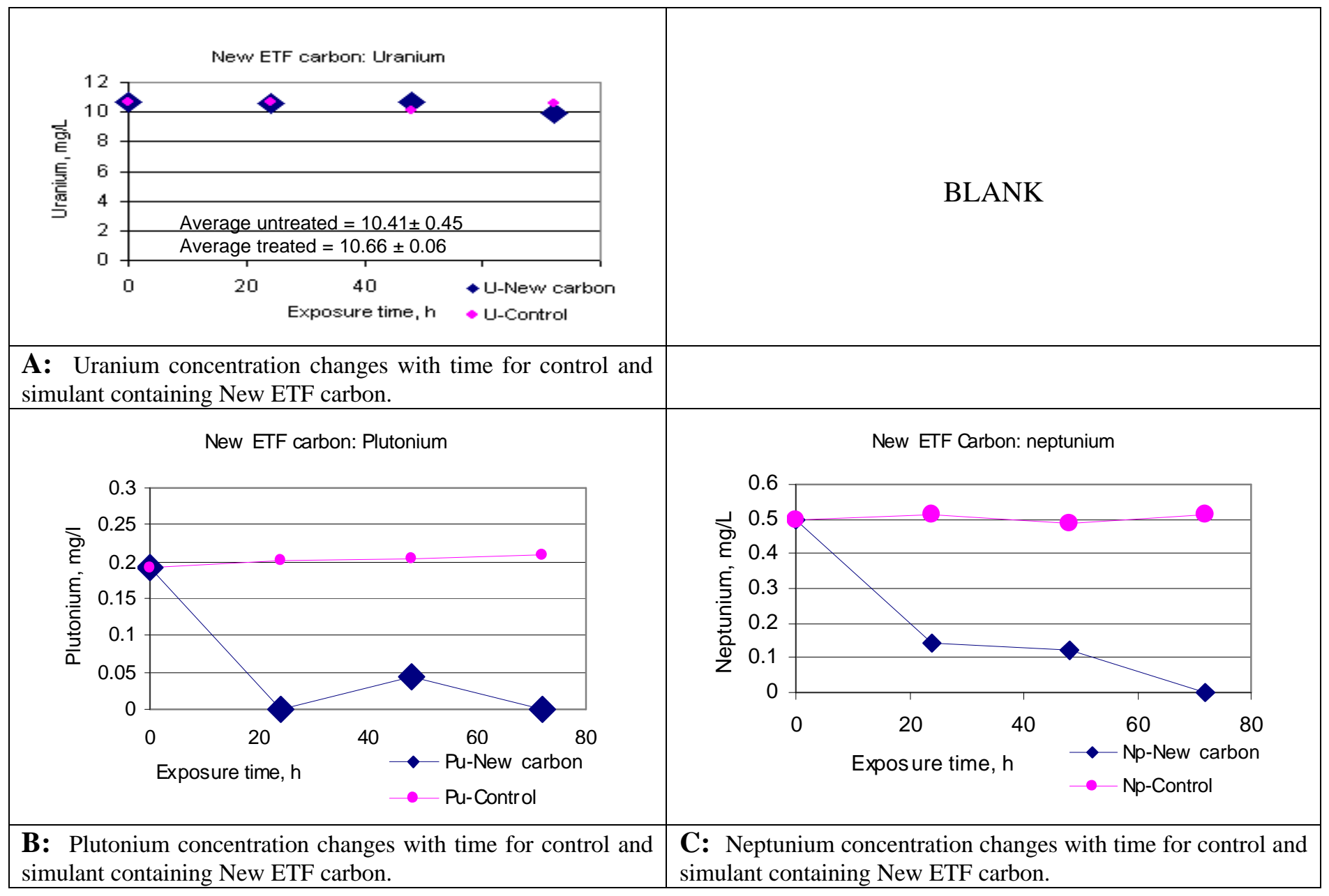

Figure 8 Changes in actinide concentration with time for new ETF activated carbon contacted with synthetic salt solution.

Since none of the materials evaluated showed signs of removing appreciable amounts of uranium from the simulant, a known uranium precipitant (anhydrous sodium phosphate) was included in the test plan to verify the test protocol.

Figure 11 inserts A and B show the results obtained with the exposure of simulant solutions to "neat" anhydrous sodium phosphate for up to 48 hours in comparison to the control runs without sodium phosphate. Sodium phosphate removed both uranium and neptunium from the simulant solution. By the end of the first 24 hours, neptunium removal had reached an equilibrium level of less than $50 \%$ of its initial concentration of $0.5 \mathrm{mg} / \mathrm{L}$ in the stimulant (Figure 11 insert B). This was not the case for uranium removal. Uranium was still being removed from solution even after 48 hours (Figure 11 insert A). By 48 hours into the test, soluble uranium concentration in the filtrate had dropped to less than $35 \%$ of its original simulant concentration of $10 \mathrm{mg} / \mathrm{L}$. 


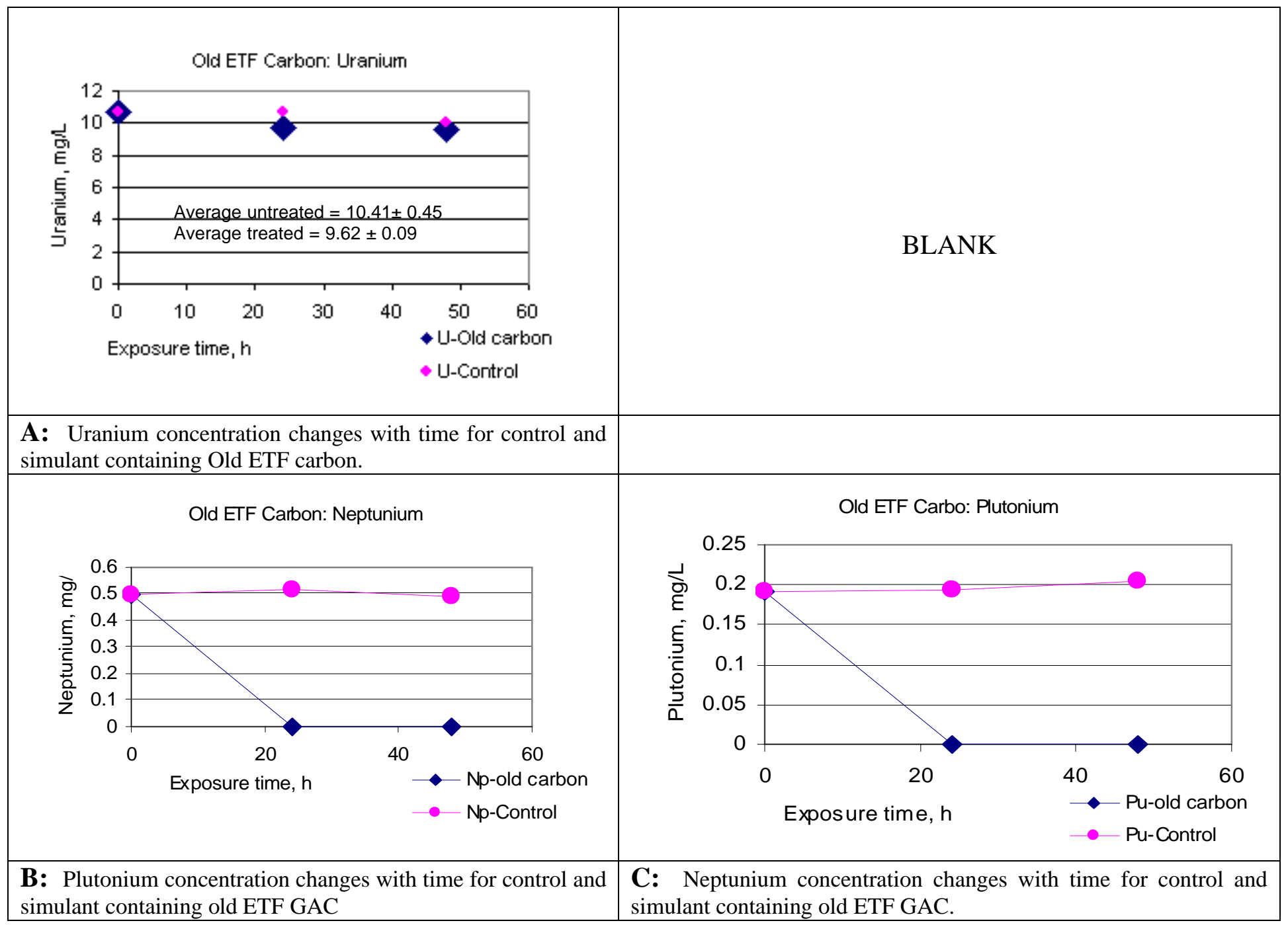

Figure 9 Changes in actinide concentration with time for Old ETF GAC contacted with synthetic salt solution.

\subsection{Potassium Tetraphenylborate and Scintillation Cocktail Interactions with Actinides}

The interaction of potassium tetraphenylborate (KTPB) with actinides in the synthetic salt solution containing plutonium, neptunium and uranium are summarized in Table 4 The results show that most of the actinides in solution were recovered after contacting the simulant solution with KTPB solids for up to 48 hours. The post contact data for the 24 and 48-hour samples show that the average neptunium concentration of $0.50 \pm 0.01$ and $0.426 \pm 0.003 \mathrm{mg} / \mathrm{L}$, respectively, were not statistically different $(2 \bullet)$ from the neptunium concentration in the control or its initial concentration in the simulant solution of $0.50 \pm$ $0.05 \mathrm{mg} / \mathrm{L}$. The plutonium post contact results with KTPB for the 24 and 48-hour samples were, respectively, $0.188 \pm 0.011$, and $0.192 \pm 0.011$. These values are not 
significantly different from the control values of $0.188 \pm 01$. Similarly, the 24 and 48hour sample results for uranium are $10.41 \pm 0.07$ and $10.39 \pm 0.02 \mathrm{mg} / \mathrm{L}$. These values are not statistically different from the observed values for the control of $9.4 \pm 0.3 \mathrm{mg} / \mathrm{L}$.

Similarly, no measurable losses of actinides were observed when scintillation cocktail was contacted with the simulant solutions. Most of the actinides were recovered after contact for up to 48 hours, see Table 5. The neptunium concentrations after contact (24 and 48-hour samples) were, respectively, $0.50 \pm 0.03$ and $0.46 \pm 0.01$. These values were within $2 \cdot$ of the of the neptunium concentration in the control $(0.51 \pm 0.03 \mathrm{mg} / \mathrm{L}$ and the original solution of $0.50 \pm 0.05 \mathrm{mg} / \mathrm{L}$. The plutonium 24 -and 48 -hour post- contact results, respectively, $0.196 \pm 002$ and $0.226 \pm 0.030 \mathrm{mg} / \mathrm{L}$, were comparable to the plutonium concentration measured in the control of $0.20 \pm 0.020 \mathrm{mg} / \mathrm{L}$.

The uranium post-contact results with scintillation cocktails for the 24 and 48-hour samples were, respectively, $10.76 \pm 0.05$, and $10.70 \pm 0.03 \mathrm{mg} / \mathrm{L}$. These values are not statistically different from the control values of $10.68 \pm 0.01 \mathrm{mg} / \mathrm{L}$ or the original simulant uranium concentration of $10.0 \pm 1.0 \mathrm{mg} / \mathrm{L}$. 
WSRC-TR-2003-00554, Rev. 0

Page 26 of 38

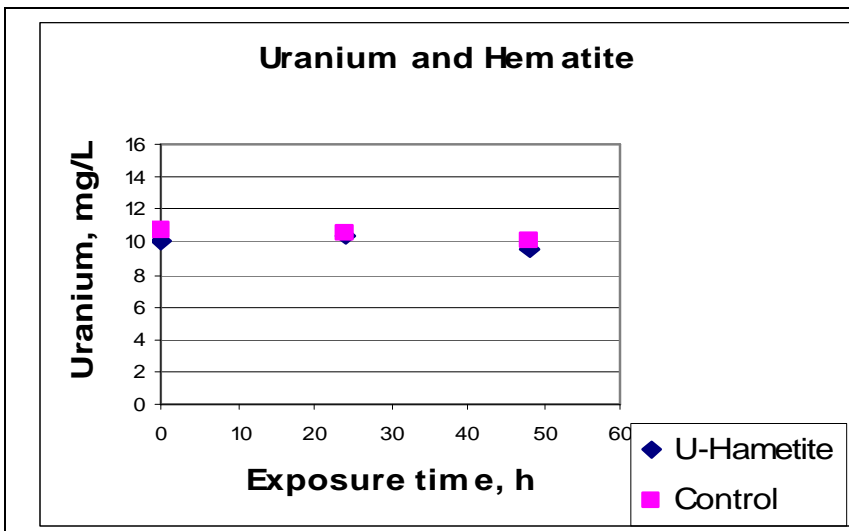

A: Overlay plot: Uranium concentration changes in control and simulant containing hematite.

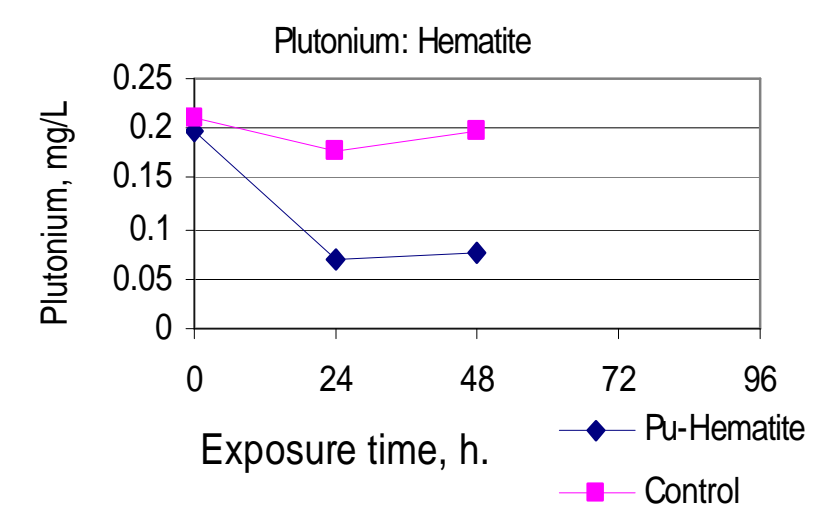

C: Overlay plot: Plutonium concentration changes in control and simulant containing hematite.

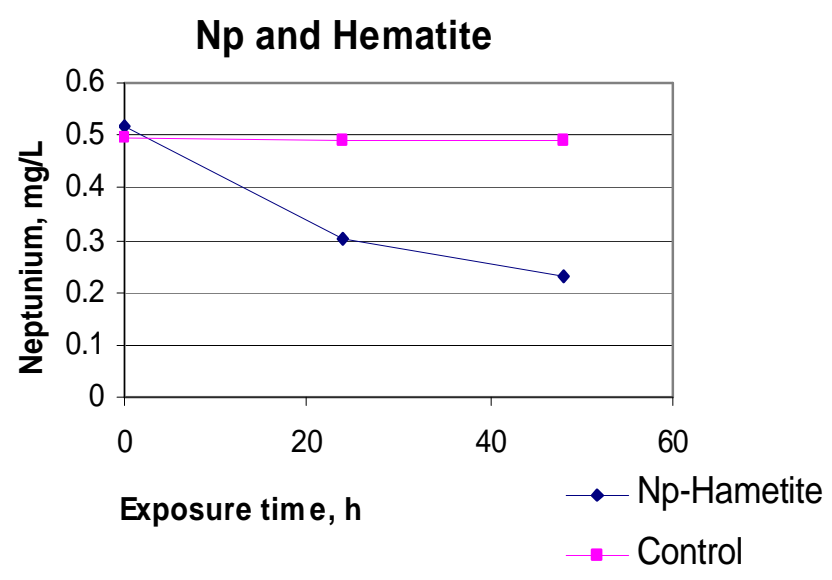

E: Overlay plot: Neptunium concentration changes in control and simulant containing hematite.

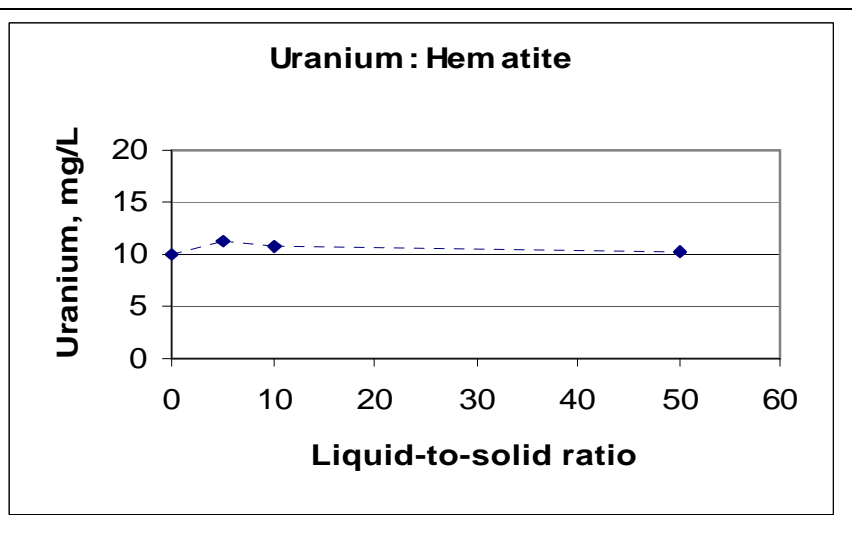

B: Uranium concentration changes with changes in liquid to-solid ratios.

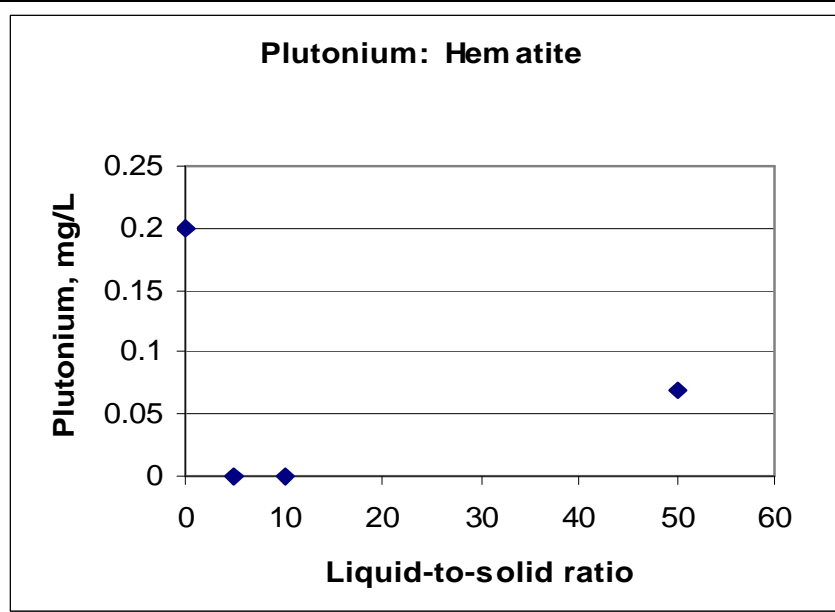

D: Plutonium concentration changes with changes in liquid to-solid ratios.

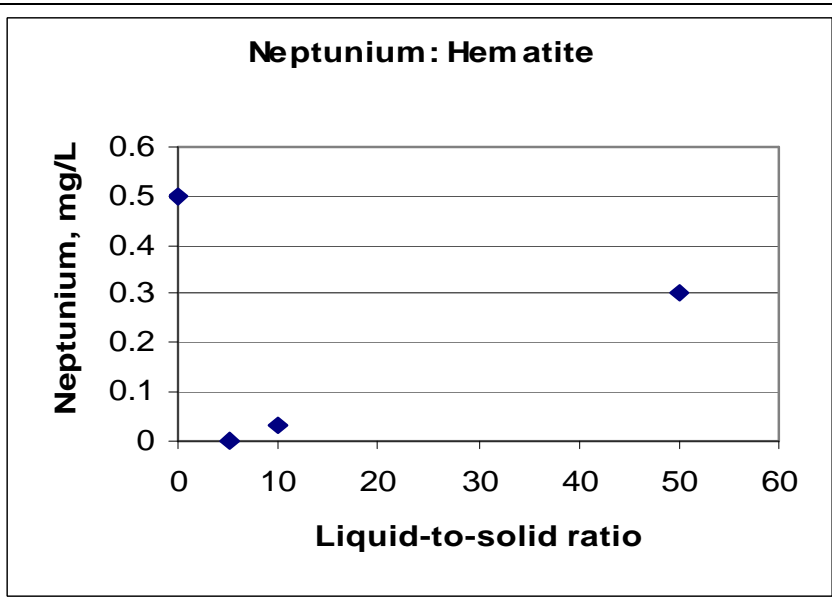

F: Neptunium concentration changes with changes in liquidto-solid ratios.

Figure 10 Changes in actinide concentration with time for hematite contacted with synthetic salt solution 
WSRC-TR-2003-00554, Rev. 0

Page 27 of 38

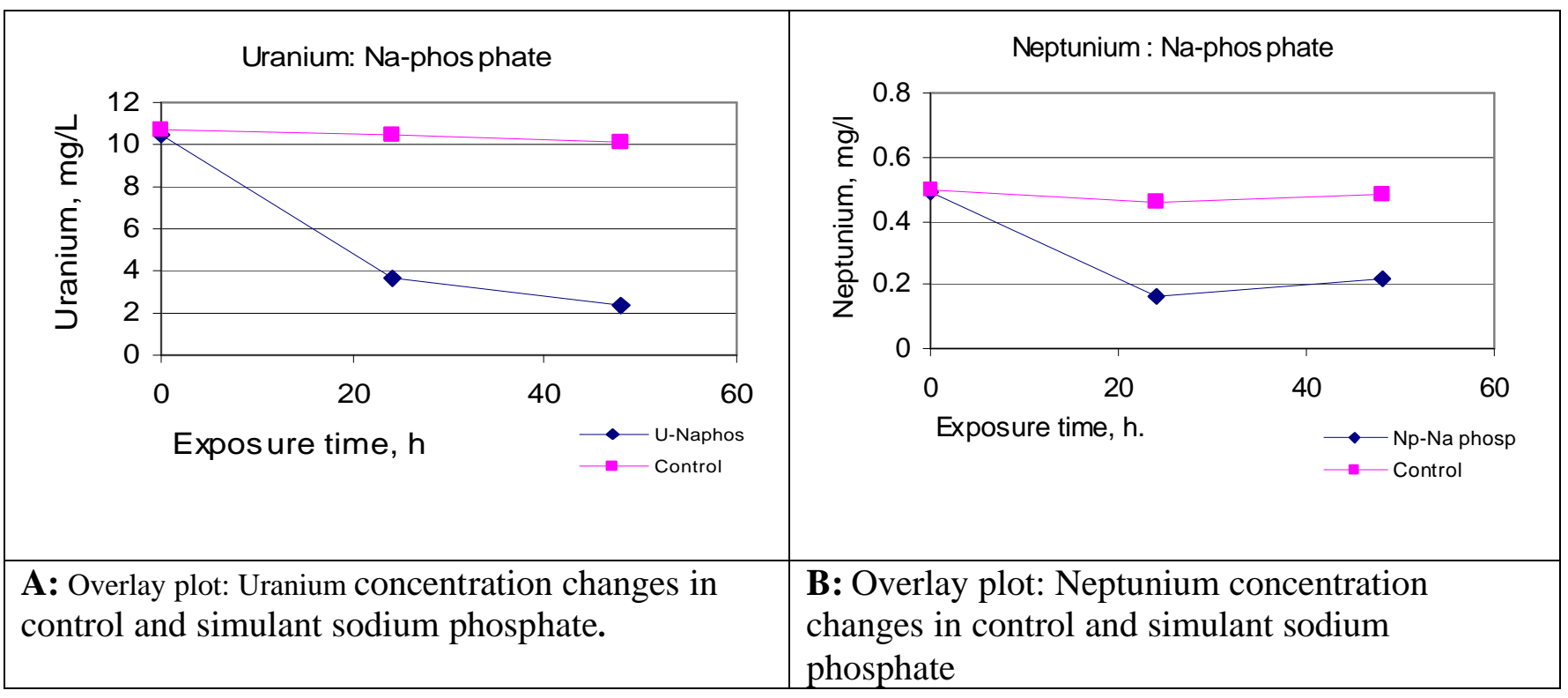

Figure 11 Changes in actinide concentration with time for sodium phosphate contacted with synthetic salt solution.

Table 4 Data summary for the interaction of actinides with potassium tetraphenylborate

\begin{tabular}{|c|c|c|c|}
\hline & $\begin{array}{c}\text { Initial } \\
\text { concentration } \\
\mathrm{mg} / \mathrm{L}\end{array}$ & $\begin{array}{c}\text { After } \\
\text { Contact } \\
\text { mg/L }\end{array}$ & Comments \\
\hline Neptunium & & & $\begin{array}{l}\text { No measurable loss of } \\
\text { neptunium }\end{array}$ \\
\hline Control & $0.5 \pm 0.05$ & $0.49 \pm 0.030$ & \\
\hline 24-hour contact & $0.5 \pm 0.05$ & $0.50 \pm 0.020$ & \\
\hline 48-hour contact & $0.5 \pm 0.05$ & $0.43 \pm 0.030$ & \begin{tabular}{|l|} 
Within $2 \bullet$ \\
\end{tabular} \\
\hline Plutonium & & & $\begin{array}{l}\text { No measurable loss of } \\
\text { plutonium }\end{array}$ \\
\hline Control & $0.2 \pm 0.02$ & $0.19 \pm 0.010$ & \\
\hline 24-hour contact & $0.2 \pm 0.02$ & $0.19 \pm 0.010$ & \\
\hline 48-hour contact & $0.2 \pm 0.02$ & $0.19 \pm 0.010$ & \\
\hline Uranium & & & No measurable loss of uranium \\
\hline Control & $10 \pm 1.0$ & $10.4 \pm 0.30$ & \\
\hline 24-hour contact & $10 \pm 1.0$ & $10.4 \pm 0.070$ & \\
\hline 48-hour contact & $10 \pm 1.0$ & $9.44 \pm 0.280$ & \\
\hline
\end{tabular}


Table 5 Data summary for the interaction of actinides with scintillation cocktail

\begin{tabular}{|l|l|l|l|}
\hline & \multicolumn{1}{|c|}{$\begin{array}{c}\text { Initial } \\
\text { concentration } \\
\mathbf{m g} / \mathbf{L}\end{array}$} & $\begin{array}{c}\text { After Contact } \\
\mathbf{m g} / \mathbf{L}\end{array}$ & Comments \\
\hline Neptunium & & & $\begin{array}{l}\text { No measurable loss of } \\
\text { neptunium }\end{array}$ \\
\hline Control & $0.5 \pm 0.05$ & $0.52 \pm 0.030$ & \\
\hline 24-hour contact & $0.5 \pm 0.05$ & $0.49 \pm 0.020$ & Within $2 \bullet$ \\
\hline 48-hour contact & $0.5 \pm 0.05$ & $0.46 \pm 0.010$ & $\begin{array}{l}\text { No measurable loss of } \\
\text { plutonium }\end{array}$ \\
\hline Plutonium & & & \\
\hline Control & $0.2 \pm 0.02$ & $0.2 \pm 0.02$ & \\
\hline 24-hour contact & $0.2 \pm 0.02$ & $0.2 \pm 0.02$ & \\
\hline 48-hour contact & $0.2 \pm 0.02$ & $0.23 \pm 0.030$ & \\
\hline & & & \\
\hline Uranium & & $10.7 \pm 0.010$ & \\
\hline Control & $10 \pm 1.0$ & $10.8 \pm 0.010$ & \\
\hline 24-hour contact & $10 \pm 1.0$ & $10.7 \pm 0.030$ & \\
\hline 48-hour contact & $10 \pm 1.0$ & & \\
\hline
\end{tabular}

\subsection{Plutonium and Neptunium Sorption Summary}

The loading results for plutonium and neptunium onto old ETF GAC, Tank $50 \mathrm{H}$ solids, Tank $50 \mathrm{H}$ solid fraction and hematite, at a liquid -to-solid ratio of 5:1, are summarized in Table 6. The old ETF GAC and Tank 50H solids loadings were run in duplicate.

The calculated average plutonium and neptunium sorbed per gram of Tank $50 \mathrm{H}$ solids, respectively 0.024 and $0.056 \mathrm{mg}$ are just about half the amounts for plutonium and neptunium sorption onto the old ETF GAC, which are respectively, 0.04 and $0.1 \mathrm{mg}$ per gram of old ETF carbon. The sorption of these actinides from the simulant solution onto hematite is $0.1 \mathrm{mg}$ plutonium per gram of hematite and $0.25 \mathrm{mg}$ neptunium per gram of hematite at this liquid-to solid ratio.

Since the Tank $50 \mathrm{H}$ solids contain, respectively, $13.5 \pm 0.5 \%$ old ETF granular activated carbon and $0.4 \%$ iron or $1.26 \%$ iron oxide $\left(\mathrm{Fe} / \mathrm{Fe}_{2} \mathrm{O}_{3}\right)($ See ICP-ES analysis for Tank $50 \mathrm{H}$ solids in reference 3 ), the amount of these actinides removed by these sorbents can be calculated based on their percent content in Tank $50 \mathrm{H}$ solids. Here we have assumed that the removal of these actinides from solution is purely by sorption and not by any other removal mechanisms such as precipitation. 
If the old ETF GAC and hematite are the only two components of the Tank $50 \mathrm{H}$ solids responsible for the removal of all the plutonium and neptunium, and if one calculates the amounts of plutonium and neptunium removed per gram of each sorbent and add them together, the result should equal the amount of each of these actinides absorbed per gram of Tank $50 \mathrm{H}$ solids. The plutonium and neptunium absorbed per gram of Tank $50 \mathrm{H}$ solids, average respectively, 0.024 and $0.056 \mathrm{mg}$ as summarized in Table 6.

A typical calculation of the amount of plutonium removal contribution by these sorbents as components of the Tank $50 \mathrm{H}$ solids, using $13.5 \%$ carbon content for Tank $50 \mathrm{H}$ solids and $1.26 \%$ hematite (reference 3 ) and the neat sorbent values in Table $6(0.1 \mathrm{mg} \mathrm{Pu} / \mathrm{g}$ hematite and $0.04 \mathrm{mg} \mathrm{Pu} / \mathrm{g}$ old ETF GAC) follows:

Plutonium:

$(0.1 \mathrm{mg} \mathrm{Pu} / \mathrm{g}$ hematite $)(0.0126 \mathrm{~g}$ hematite/g Tank $50 \mathrm{H}$ solids $)+(0.04 \mathrm{mg} \mathrm{Pu} / \mathrm{g}$ old ETF GAC $)(0.135 \mathrm{~g}$ old ETF GAC/g Tank $50 \mathrm{H}$ solids $)=0.0067 \mathrm{mg} \mathrm{Pu} /$ gram Tank $50 \mathrm{H}$ solids. The percent $\mathrm{Pu}$ absorbed as a result of the combined presence of old ETF GAC and hematite in Tank $50 \mathrm{H}$ solids is therefore about $28 \% \quad(100-[(((0.024-$ $0.0067)) / 0.024) * 100])$.

Similarly for neptunium, (0.25 mg Np/ g hematite)(0.0126 g hematite/g Tank $50 \mathrm{H}$ solids) $+(0.1 \mathrm{mg} \mathrm{Np} / \mathrm{g}$ old ETF carbon $)(0.135 \mathrm{~g}$ old ETF carbon $/ \mathrm{g}$ Tank $50 \mathrm{H}$ solids $)=\underline{0.0166 \mathrm{mg}}$ $\mathrm{Np} /$ gram Tank $50 \mathrm{H}$ solids. The percent $\mathrm{Np}$ sorbed as a result of the combined presence of old ETF activated carbon and hematite in Tank $50 \mathrm{H}$ solids is also about $30 \%$ (100$[(((0.056-0.0166)) / 0.056) * 100])$.

Hence, these results of the single components tests account for only $30 \%$ of the observed plutonium and neptunium sorbed by the Tank $50 \mathrm{H}$ solids. The assumption here is that the chemical and physical properties of the "neat" components evaluated are not significantly different from the similar components in the Tank $50 \mathrm{H}$ solids. Since these "neat" components do not account for the other $70 \%$ plutonium and neptunium removal from the synthetic salt solution by the Tank $50 \mathrm{H}$ components, other components of the Tank $50 \mathrm{H}$ solids, not evaluated here, may also be responsible for actinide removal.

Table 7 shows a summary of selected transition metal cations that are components of the Tank $50 \mathrm{H}$ solids (reference 3 ). From literature, ${ }^{7,8,9}$ these transition metal cations in their oxide forms are known efficient absorbents of plutonium and neptunium. Manganese oxide is known to have significantly higher affinity for plutonium and neptunium than does hematite. ${ }^{5,10}$ Thus, the manganese present in the Tank $50 \mathrm{H}$ solids, may responsible for the sorption of plutonium and neptunium not accounted for by the activated carbon and hematite. 
WSRC-TR-2003-00554, Rev. 0

Page 30 of 38

Table 6 Plutonium and neptunium removed from synthetic salt solution per gram of sorbent after 24 hours contact.

\begin{tabular}{|c|c|c|c|c|c|}
\hline & $\begin{array}{l}\text { Old ETF }^{1} \\
\text { GAC }\end{array}$ & $\begin{array}{l}\text { Tank 50H }{ }^{2} \\
\text { solids }\end{array}$ & $\begin{array}{l}\text { Tank 50H solid } \\
\text { Fraction* }^{3}\end{array}$ & Hematite $^{4}$ & $\begin{array}{l}\text { Liquid-to- } \\
\text { solid ratio }\end{array}$ \\
\hline Units & $\begin{array}{l}\text { mg Pu/g } \\
\text { sorbent }\end{array}$ & $\begin{array}{lrl}\text { mg Pu/ } & \text { g } \\
\text { sorbent }\end{array}$ & mg Pu/g sorbent & $\begin{array}{l}\mathrm{mg} \mathrm{Pu} / \mathrm{g} \\
\text { sorbent }\end{array}$ & \\
\hline $\mathbf{P u}$ & 0.04 & 0.022 & 0.020 & 0.10 & $5: 1$ \\
\hline $\mathbf{P u}$ & 0.04 & 0.025 & 0.020 & NA & $5: 1$ \\
\hline Units & $\begin{array}{c}\mathrm{mg} \mathrm{Np} / \mathrm{g} \\
\text { sorbent }\end{array}$ & $\begin{array}{c}\mathrm{mg} \mathrm{Np} / \mathrm{g} \\
\text { sorbent }\end{array}$ & mg Np/g sorbent & $\begin{array}{c}\mathbf{m g ~ N p} / \mathbf{g} \\
\text { sorbent }\end{array}$ & \\
\hline $\mathbf{N p}$ & 0.10 & 0.054 & 0.050 & 0.25 & $5: 1$ \\
\hline $\mathbf{N p}$ & 0.10 & 0.059 & 0.050 & NA & $5: 1$ \\
\hline
\end{tabular}

* Calculated by graphing the 8:1 and 25:1 liquid-to-solid ratio data and determining what the 5:1 ratio would be based on the generated linear functions $\left(\mathrm{Y}_{\mathrm{Np}}=0.0072\right.$ ratio +0.01141 and Ypu= 0.003 ratio +0.005$)$.

1. From Figure 9

2. From Figure 4

3. From Figure 5

4. From figure 10

Table 7 Transition metal cation and Activated Carbon content in Tank 50H solids*

\begin{tabular}{|c|c|c|c|c|}
\hline $\begin{array}{c}\text { Transition metal } \\
\text { cation or } \\
\text { Activated carbon }\end{array}$ & $\begin{array}{c}\text { mg/g Tank } \\
\mathbf{5 0 H} \text { solids }\end{array}$ & $\begin{array}{l}\text { Equivalent } \\
\text { metal oxide }\end{array}$ & $\begin{array}{c}\text { mg metal } \\
\text { oxide /g Tank } \\
\mathbf{5 0 H} \text { solids }\end{array}$ & \% metal oxide \\
\hline $\mathbf{F e}$ & & & & \\
\hline $\mathbf{M n}$ & 4.40 & $\mathrm{Fe}_{2} \mathrm{O}_{3}$ & 12.60 & 1.26 \\
\hline $\mathbf{Z n}$ & 0.24 & $\mathrm{MnO}_{2}$ & 0.620 & 0.0620 \\
\hline $\mathbf{C r}$ & 0.325 & $\mathrm{ZnO}$ & 0.448 & 0.0484 \\
\hline $\mathbf{T i}$ & 0.062 & $\mathrm{Cr}_{2} \mathrm{O}_{3}$ & 0.181 & 0.0180 \\
\hline & 0.07 & $\mathrm{TiO}$ & 0.117 & 0.0117 \\
\hline Old ETF GAC & 0.135 & - & & 13.5 \\
\hline
\end{tabular}

* From reference 3. 
WSRC-TR-2003-00554, Rev. 0

Page 31 of 38

\subsection{Plutonium and Neptunium Loading Curves with "Neat" ETF Carbons, Hematite, and Sodium phosphate.}

Loading curves for plutonium, neptunium and uranium were calculated for various "neat" sorbents using results from equilibrium tests over a range of simulant-to-solid ratios. Since none of the single components identified in the Tank $50 \mathrm{H}$ solids showed measurable uranium sorption, the only uranium loading curve obtained was for the control (sodium phosphate).

The loading curves presented here are based on a minimum of six different simulant-tosolid ratios. The concentration of each actinide on the solid phase was calculated from the difference between the initial and final solution concentration. The solids were not analyzed. Figures 12, Figure 13, and Figure 14 show neptunium-237 and plutonium-239 loading curves, respectively, for the old ETF granular activated carbon, the new ETF activated carbon, and hematite after 24 hours exposure to the simulant solution at room temperature. Figure 15, inserts A and B show, respectively, the loading curves on sodium phosphate for neptunium-237 and uranium after 24 hours of exposure to the simulated salt solution bearing these actinides.

Some of the loading curves presented in the graphs, for example Figure 14 insert A for loading of neptunium onto hematite, do not have sufficient data points to clearly characterize the maximum loading area of the curve, which is the plateau region of the Langmuir isotherm. The sorption equilibrium for these actinides under these conditions may not have been attained after 24 hours of contacting them with the sorbents. To estimate what the maximum actinide loading values are at the plateau region of the curves a second degree polynomial fitting was used for all the loading data. The use of a second degree polynomial fitting function for the loading curve data applies only up to the inflection point of the curve and not beyond that point and only if that point falls within the data set. CAUTION! These equations may not be used to extrapolate to values outside the data set.

Thus, a second degree polynomial regression of the data, Figures 12 through 15 provides the following equations for estimating maximum loading of plutonium-239, neptunium237, and uranium (sodium phosphate only) on these precipitants:

\section{Plutonium-239:}

$y=-0.0518 x^{2}+16.029 x+7.3876$ for new ETF activated carbon

$y=-9 E-05 x^{2}+0.0352 x$ for old ETF GAC

$y=-0.0004 x^{2}+0.0959 x$ for hematite

Neptunium-237:

$\mathrm{y}=-3 \mathrm{E}-05 \mathrm{x}^{2}+0.0212 \mathrm{x}-0.0247$ for new ETF activated carbon

$y=-6 E-05 x^{2}+0.044 x$ for old ETF GAC 
Projected value, $y=-2 E-05 x^{2}+0.0344 x-0.1176$, is outside of data set for hematite (see Figure 14 insert A).

$y=-37.53 x^{2}+31.807 x$ for sodium phosphate

\section{Uranium:}

$y=-4.183 x^{2}+55.584 x$ for sodium phosphate,

where $\mathrm{y}$ is loading capacity in units of $\mu \mathrm{g}$ actinide per gram of "neat" sorbent material and $\mathrm{x}$ is the final actinide concentration in $\mu \mathrm{g} / \mathrm{L}$. By equating the first derivatives of each loading capacity equation above to zero and solving for $\mathrm{x}$ values, the maximum loading capacities (y-values) for plutonium and neptunium were determined from the absorption data.

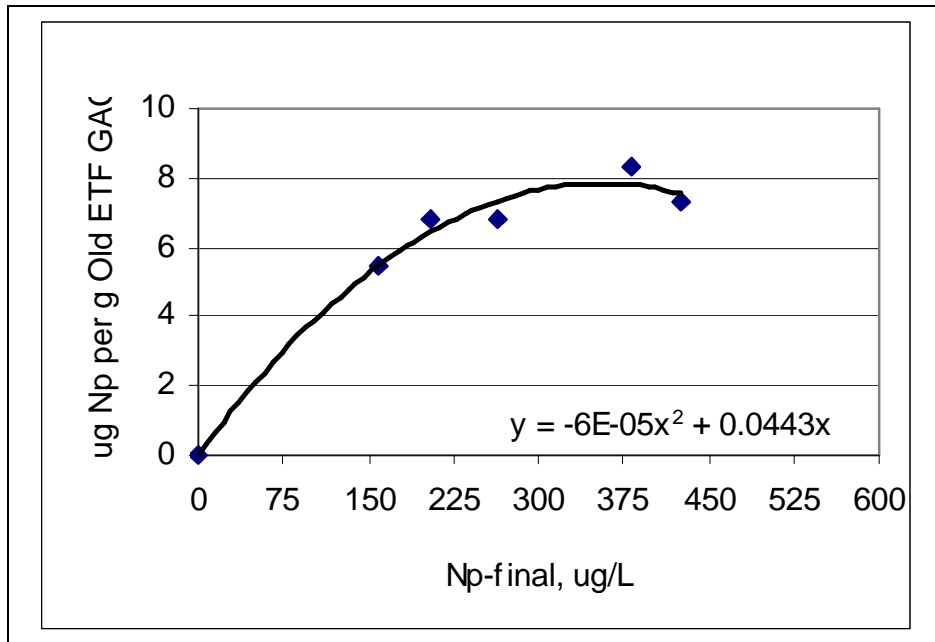

A: 24-hour neptunium-237 loading curve for old ETF GAC

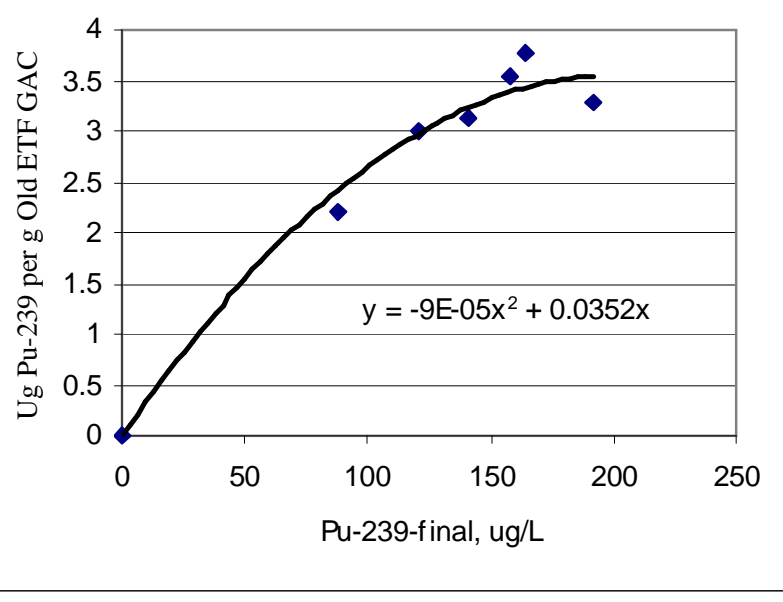

B: 24-hour plutonium-239 loading curve for Old ETF GAC

Figure 12 Neptunium and plutonium loading curves for Old ETF Activated carbon. 
WSRC-TR-2003-00554, Rev. 0

Page 33 of 38

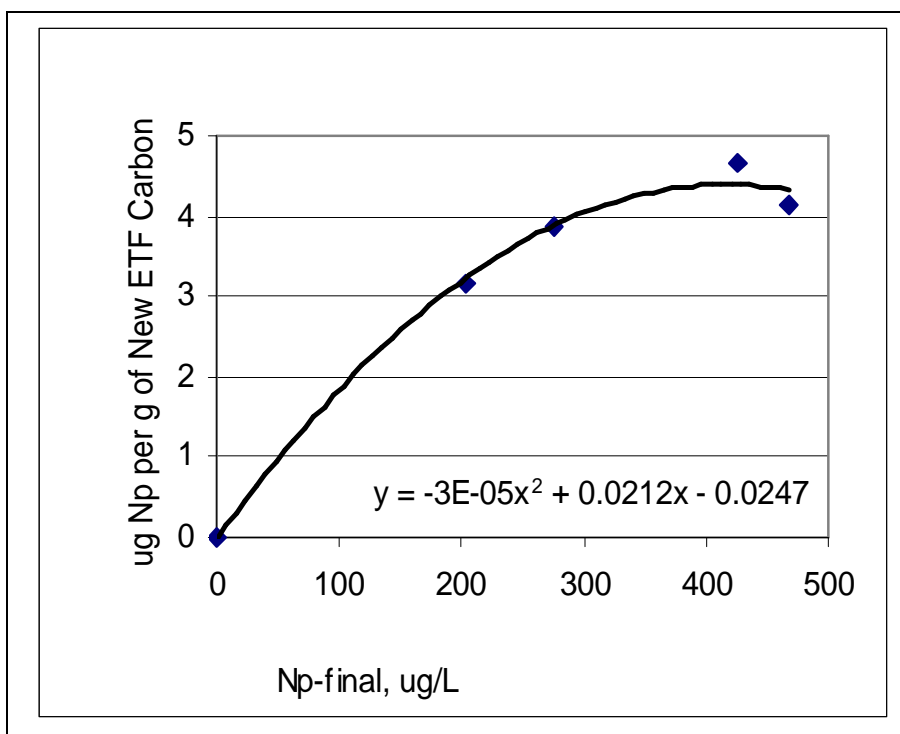

A: 24-hour neptunium-237 loading curve for new ETF activated carbon

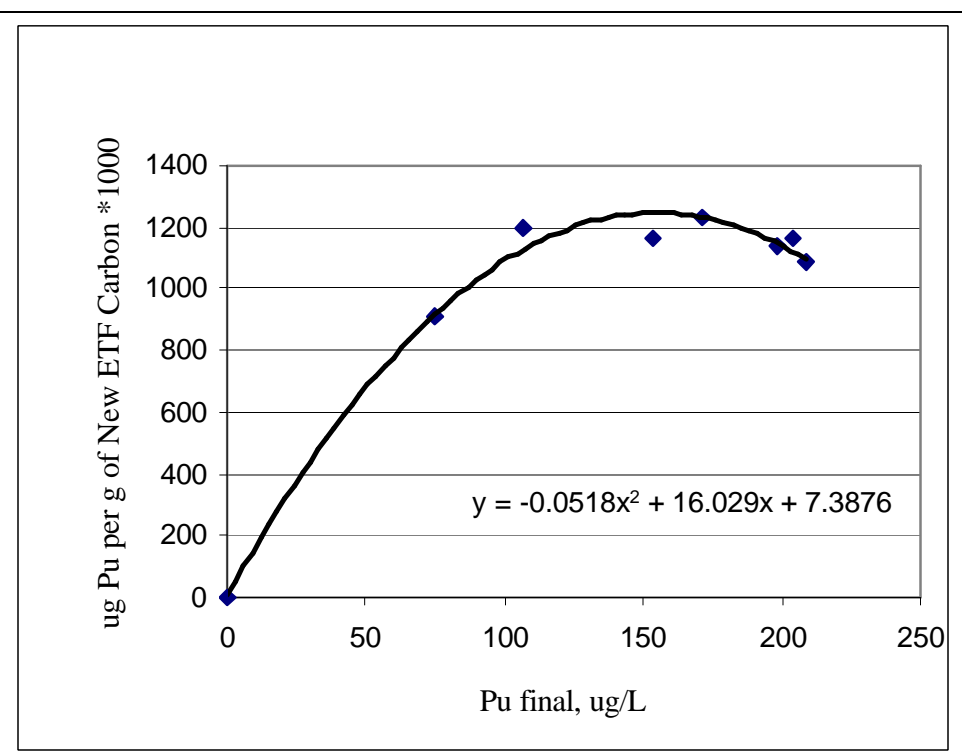

B: 24 hour plutonium-239 loading curve for new ETF Carbon

Figure 13 Neptunium and plutonium loading curves for New ETF activated carbon.

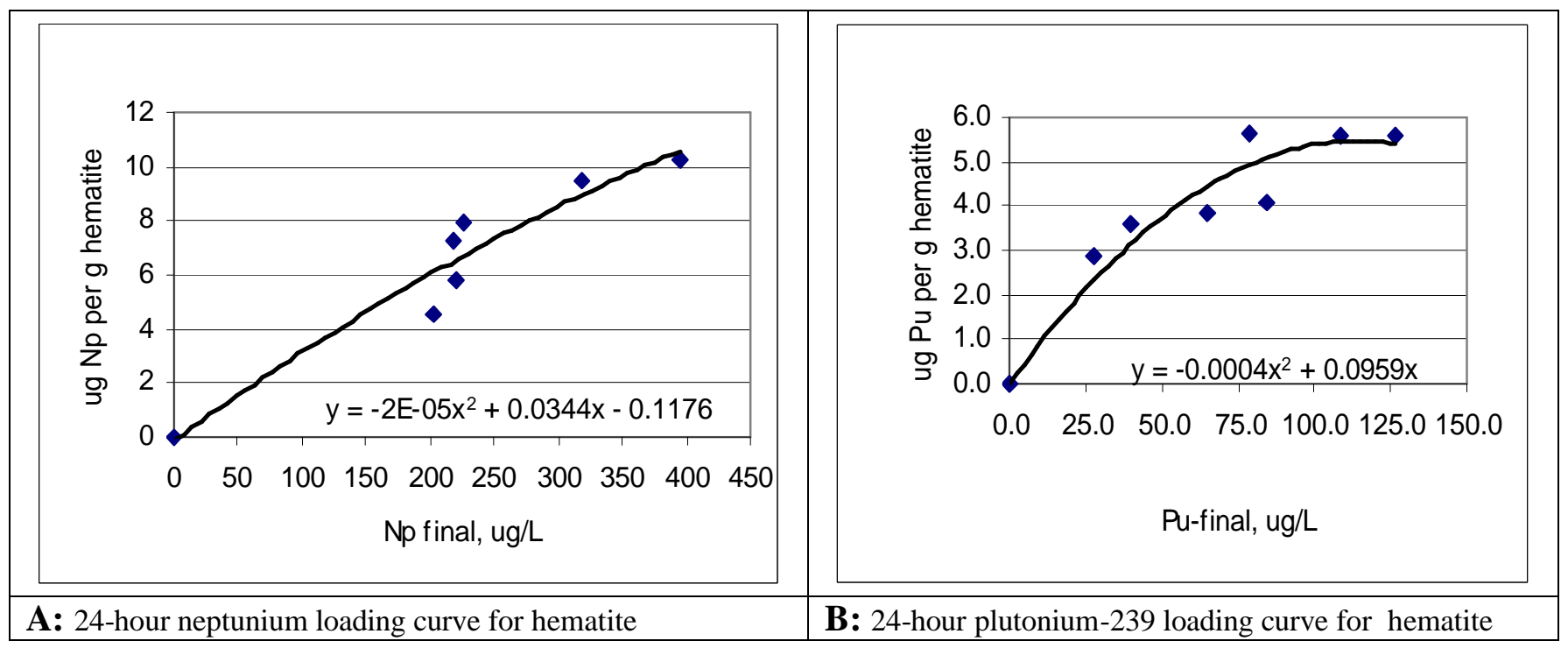

Figure 14 Neptunium and plutonium loading curves for hematite. 


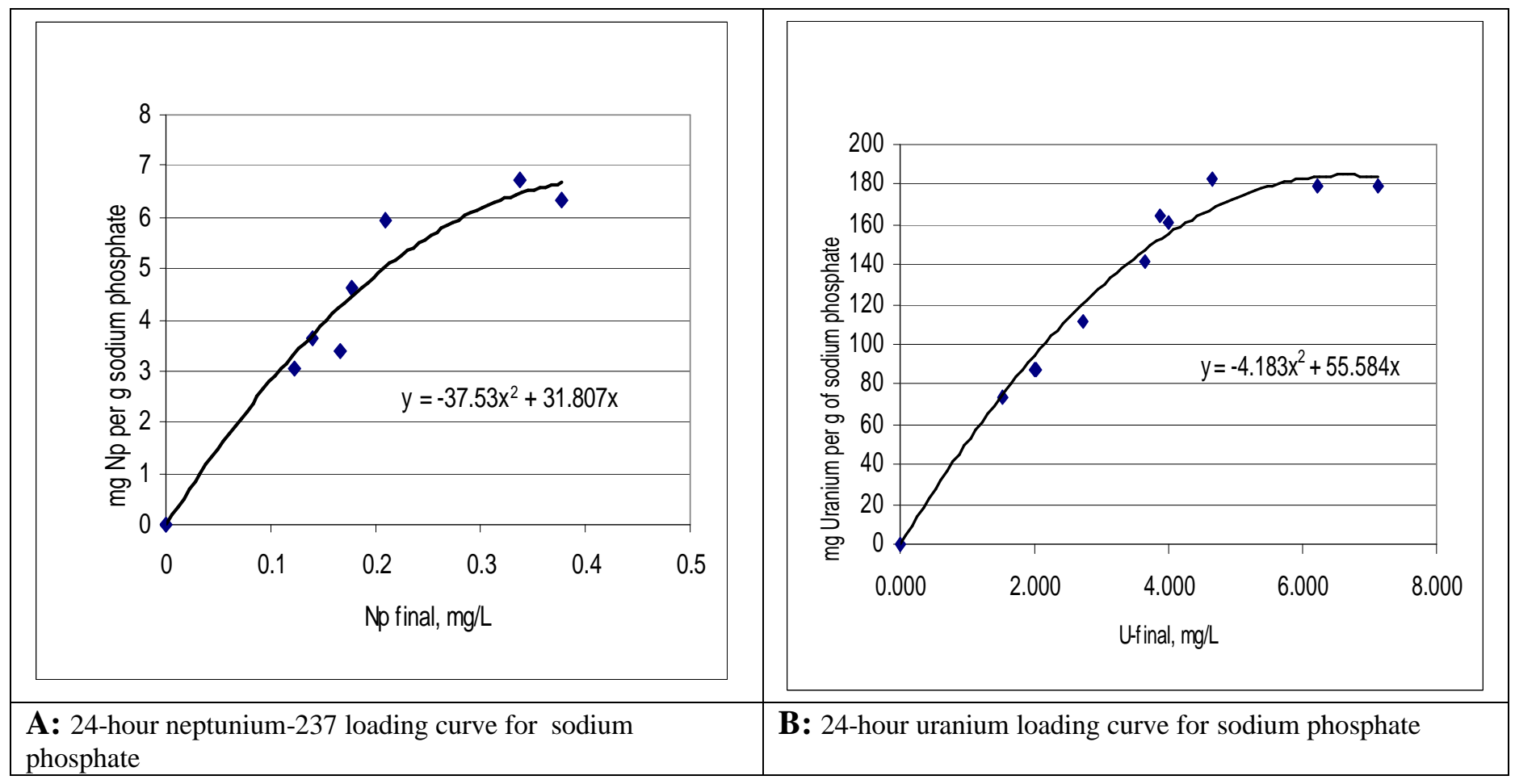

Figure 15 Neptunium and uranium loading curves for sodium phosphate.

Table 8 shows a summary of loading data for plutonium, neptunium and uranium on, respectively, Tank $50 \mathrm{H}$ solids ${ }^{4}$, "neat" old and new ETF carbons, "neat" hematite and sodium phosphate. Based on these loading curve data, "neat" hematite and "neat" old ETF activated carbon have the highest affinity for both plutonium and neptunium at, respectively, $5.5 \pm 0.38$ and $>10 \mu \mathrm{g}$ per gram hematite and $7.9 \pm 0.52$ and $3.6 \pm 0.22 \mu \mathrm{g}$ per gram old ETF activated carbon. The new ETF carbon with a loading of $1.3 \pm 0.070$ $\mu \mathrm{g}$ plutonium and $4.4 \pm 0.44 \mu \mathrm{g}$ neptunium per gram, exhibits lower affinity for these actinides than the old ETF granulated activated carbon. Sodium phosphate (used here as a reference sorbent for uranium) as expected exhibited a very high affinity for uranium. Its affinity for neptunium was comparable to that of the old ETF activated carbon, although it showed no measurable affinity for plutonium. Both uranium and neptunium were readily absorbed in the presence of anhydrous sodium phosphate. The loading capacity values were, respectively, $184.6 \pm 18.5$ and $6.8 \pm 0.6 \mu \mathrm{g}$ per gram of anhydrous sodium phosphate.

Therefore, the relative order for loading plutonium and neptunium onto these sorbents is iron oxide (hematite) > old ETF GAC > New ETF activated carbon >> Tank $50 \mathrm{H}$ solids.

Loading capacity information provides a basis for estimating the maximum volume of Tank Farm supernates that can be transferred into the Tank $50 \mathrm{H}$ before accumulating sufficient quantities of plutonium to pose a nuclear criticality safety concern. Conversely, the information could be used to determine how much of the Tank solids could be left behind and not present a safety concern due to the accumulation of plutonium and 
neptunium. The loading capacities for plutonium and neptunium with Tank $50 \mathrm{H}$ solids contacted with synthetic salt solutions bearing soluble levels of these actinides are, respectively, 2.01 and $4.48 \mu \mathrm{g}$ per gram of Tank $50 \mathrm{H}$ solids. ${ }^{4}$ But for plutonium and neptunium loading capacities onto "neat" hematite, these Tank $50 \mathrm{H}$ solids loading capacities for plutonium and neptunium are within 40-50\% loading capacities for plutonium and neptunium onto "neat" ETF GAC as summarized in Table 8.

This result also supports the finding that an additional component in the $50 \mathrm{H}$ solids, besides activated carbon and iron oxides, contributes to the observed sorption of plutonium and neptunium.

Table 8 Loading curve summary

\begin{tabular}{|l|l|c|c|}
\hline Solids & $\begin{array}{l}\text { Maximum loading } \\
\boldsymbol{\mu g} / \mathbf{g} \text { solid }\end{array}$ & $\begin{array}{l}\text { Maximum loading } \\
\boldsymbol{\mu g} / \mathbf{g} \text { solid }\end{array}$ & $\begin{array}{l}\text { Maximum loading } \\
\boldsymbol{\mu g} / \mathbf{g} \text { solid }\end{array}$ \\
\hline & & $\mathrm{Np}$ & $\mathrm{U}$ \\
\hline & $\mathrm{Pu}$ & 4.48 & $\mathrm{NA}$ \\
\hline Tank 50H solids* & 2.01 & & $\mathrm{NA}$ \\
\hline & & $7.9 \pm 0.52$ & $\mathrm{NA}$ \\
\hline Old ETF GAC & $3.6 \pm 0.22$ & $4.4 \pm 0.44$ & $\mathrm{NA}$ \\
\hline New ETF Carbon & $1.3 \pm 0.070$ & & \\
\hline Iron Oxide (hematite) & $5.5 \pm 0.38$ & $>10.0$ & $184.6 \pm 18.5$ \\
\hline & & & $>6.0$ \\
\hline Sodium phosphate (anhyd.) & Not measured & & \\
\hline
\end{tabular}

NA $=$ No measurable absorption of uranium.

- $\quad$ See reference 4.

\subsection{CONCLUSIONS}

Based on the batch experiments performed in this study the following conclusions are made:

- The removal of plutonium and neptunium from the synthetic salt solution by Tank $50 \mathrm{H}$ solids is due largely to the presence of the old ETF granular activated carbon and transition metal oxides, likely iron and manganese oxides, in Tank $50 \mathrm{H}$ solids. These components of the Tank $50 \mathrm{H}$ solids are known active sorbents of both plutonium and neptunium.

- Both activated carbon and iron oxide (hematite), which are components of Tank $50 \mathrm{H}$ solids, contribute to the removal of $\mathrm{Pu}$ and $\mathrm{Np}$ by Tank $50 \mathrm{H}$ solids and in combination, they account for about $30 \%$ of the $\mathrm{Pu}$ and $\mathrm{Np}$ removed by Tank $50 \mathrm{H}$ solids. 
- Nitrated cancrinite in contact with simulant salt solution containing uranium, plutonium and neptunium does not show any measurable tendency to remove these actinides from salt solution.

- The two forms of activated carbon investigated in these tests show measurable affinity for plutonium and neptunium.

- The new ETF activated carbon did not remove any measurable amount of uranium from the simulant salt solution, while the old ETF carbon removed less than $10 \%$ of the uranium.

- The new ETF activated carbon exhibits lower affinity for plutonium and neptunium than the old ETF carbon.

- The old ETF granular activated carbon and iron oxide (hematite) exhibit high affinity for both plutonium and neptunium.

- Hematite exhibits greater affinity for plutonium and neptunium than the ETF carbons.

- Both potassium tetraphenylborate and scintillation cocktail did not show any measurable interaction or removal of uranium, plutonium and neptunium from the synthetic salt solution.

- Sodium phosphate (used here as a reference sorbent for uranium), as expected, exhibited high affinity for uranium and neptunium, but failed to show any measurable affinity for plutonium.

- Plutonium and neptunium loading capacity onto "Neat" old ETF granular activated carbon are, respectively, $3.6 \pm 0.22$ and $7.9 \pm 0.52 \mu \mathrm{g}$ per gram of old ETF granulated activated carbon.

- Plutonium and neptunium loading capacity onto "Neat" new ETF activated carbon are, respectively, $1.3 \pm 0.070$ and $4.4 \pm 0.44 \mu \mathrm{g}$ per gram of new ETF activated carbon.

- The loading capacity for plutonium and neptunium onto hematite are, respectively, $5.5 \pm 0.38$ and $>10 \mu \mathrm{g}$ per gram of hematite.

- Plutonium loading capacity onto the Tank $50 \mathrm{H}$ solids $(2.01 \mu \mathrm{g}$ per gram of Tank $50 \mathrm{H}$ solids) is about $60 \%$ of plutonium loading capacity onto "neat" ETF granular activated carbon and $40 \%$ of plutonium loading capacity onto "neat" hematite.

- Neptunium loading capacity onto the Tank $50 \mathrm{H}$ solids $(4.48 \mu \mathrm{g}$ per gram of Tank $50 \mathrm{H}$ solids) is about $50 \%$ of plutonium loading capacity onto "neat" ETF granular activated carbon and less than $50 \%$ of neptunium loading capacity onto "neat" hematite (iron oxide). 
WSRC-TR-2003-00554, Rev. 0

Page 37 of 38

Additional testing to verify if other transition metal oxides $\left(\mathrm{MnO}_{2}\right.$ and $\left.\mathrm{ZnO}\right)$ are responsible for actinide removal not accounted for by the presence of activated carbon and hematite is recommended.

\subsection{QUALITY ASSURANCE}

This study fulfills the activity defined in Task Technical and Quality Assurance Plan: "Identification of Tank 50H Solids Components Responsible for Removal of Dissolved Actinides" WSRC-RP-2003-0388, Rev.0, April 17, 2003. Data obtained from this study reside as records in WSRC-LB-2001-00179.

\subsection{ACKNOWLEDGEMENTS}

The authors thank Analytical Development Section personnel, in particular, W. Boyce, M. Malek, David and Cecilia Diprete and J. Hart for performing actinide, anion, and other metal analyses. We also thank M. S. Blume for assistance in running the experiments.

\subsection{REFERENCES}

${ }^{1}$ Banaszewski, C.D., "Tank 50 Solids Mound Volume Calculation", J-CLC-H-00793, Rev. 0, November 2002.

2 Banaszewski, C.D., "Engineering Path Forward HTF-PF-2002-0014: Tank 50H Solids (U)", HLW-STE-2002-00388, October 23,2002.

${ }^{3}$ Wilmarth, W.R., "Results of Sample Analysis from Solids Removed from Tank 50H", WSRC-TR-2002-00506, November 1,2002.

${ }^{4}$ Oji 1. N. and Hobbs D. T., "Evaluation of the Effects of Tank 50H Solids on Dissolved

Uranium, Plutonium and Neptunium”, WSRC-RP-2003-00224, Rev. 0, April 17, 2003.

${ }^{5}$ S. Nagasaki, S. Tanaka and A. Suzuki, "Influence of Fe (III) colloids on Np (V) migration through quartz-packed columns," Journal of Nuclear Science Technology, 31(2), pp 143-150 (Feb. 1994).

${ }^{6}$ M. Kohler, B. D. Honeyman and J. O. Leckie “ Neptunium (V) sorption on hematite (•$\mathrm{Fe}_{2} \mathrm{O}_{3}$ ) in aqueous suspension: the effect of $\mathrm{CO}_{2}$," Radiochim. Acta 85, 33-48 (1999).

${ }^{7}$ J. L. Means, D. A. Crerar, M. P. Borscsik and J. O. Duguid, "Adsorption of Co and selected actinides by $\mathrm{Mn}$ and Fe oxides in soils and sediments," Geochim. Cosmochim. Acta, 42, 1763-1773 (1978).

${ }^{8}$ S.A. Slater, D. B. Chamberlain, D. B. Aase, S. A, Babcock, B. D. Conner, C. Sedlet and G. F. Vandergrift, "Optimization of magnetite Carrier precipitation process for plutonium waste reduction,” Sep. Sci. Technol.., 32 127-147 (1997). 
${ }^{9}$ R.S. Sidhu and P. Hoff, "Rapid determination of environmental plutonium in large water samples by means of manganese dioxide co-precipitation and extraction chromatography separation," Radiochim. Acta, 8489-93 (1999).

${ }^{10}$ Radioactivity in the Environment, Volume 1: Plutonium in the Environment, Elsevier 2001; M. C. Duff, "Speciation and transformation of Sorbed Pu on geological materials: wet chemical and spectroscopic observations," pages 139-157. 